Subscriber access provided by Aston University Library \& Information Services

Controlled Release and Delivery Systems

\title{
The antimicrobial efficacy of hypoxia mimicking cobalt oxide doped phosphate-based glasses against clinically relevant Gram positive, Gram negative bacteria and a fungal strain.
}

Farah N. S. Raja, Tony Worthington, Mark A. Isaacs, Louis Forto

Chungong, Bernie Burke, Owen Addison, and Richard Alan Martin

ACS Biomater. Sci. Eng., Just Accepted Manuscript • DOI: 10.1021/

acsbiomaterials.8b01045 • Publication Date (Web): 19 Nov 2018

Downloaded from http://pubs.acs.org on November 22, 2018

\section{Just Accepted}

"Just Accepted" manuscripts have been peer-reviewed and accepted for publication. They are posted online prior to technical editing, formatting for publication and author proofing. The American Chemical Society provides "Just Accepted" as a service to the research community to expedite the dissemination of scientific material as soon as possible after acceptance. "Just Accepted" manuscripts appear in full in PDF format accompanied by an HTML abstract. "Just Accepted" manuscripts have been fully peer reviewed, but should not be considered the official version of record. They are citable by the Digital Object Identifier (DOI®). "Just Accepted" is an optional service offered to authors. Therefore, the "Just Accepted" Web site may not include all articles that will be published in the journal. After a manuscript is technically edited and formatted, it will be removed from the "Just Accepted" Web site and published as an ASAP article. Note that technical editing may introduce minor changes to the manuscript text and/or graphics which could affect content, and all legal disclaimers and ethical guidelines that apply to the journal pertain. ACS cannot be held responsible for errors or consequences arising from the use of information contained in these "Just Accepted" manuscripts. 


\title{
The antimicrobial efficacy of hypoxia mimicking cobalt oxide doped phosphate-based glasses against clinically relevant Gram positive, Gram negative bacteria and a fungal strain.
}

Farah N. S. Raja ${ }^{1}$, T. Worthington ${ }^{1}$, Mark A. Isaacs ${ }^{2}$, Louis Forto Chungong ${ }^{3}$, Bernard Burke ${ }^{4,5}$, Owen Addison ${ }^{5,6}$ and Richard A. Martin ${ }^{3 *}$.

1. School of Life \& Health Science and Aston Research Centre for Healthy Ageing, Aston University, Aston Triangle, Birmingham, B4 7ET, UK

2. Department of Chemistry, University College London, 20 Gordon Street, Kings Cross, London, WC1H 0AJ

3. School of Engineering \& Applied Science and Aston Institute of Materials Research. Aston University, Aston Triangle, Birmingham, B4 7ET, UK

4. School of Life Sciences, Coventry University, Coventry, CV1 2DS, UK

5. Biomaterials Unit, University of Birmingham School of Dentistry, Birmingham, B5 7EG, UK

6. University of Alberta, School of Dentistry, Edmonton, Alberta, Canada, T6G 1C9

\author{
AUTHOR INFORMATION \\ Corresponding Author \\ *E-mail: r.a.martin@Aston.ac.uk. Tel.: +44 (0)121 2045111.
}

\section{ORCID}

Richard A. Martin: 0000-0002-6013-2334

Keywords

Bioactive glass, antibacterial, vascularisation, VEGF, Hypoxia Inducible Factor-1 $\alpha(\mathrm{HIF}-1 \alpha)$ 


\begin{abstract}
Bioactive phosphate glasses are of considerable interest for a range of soft and hard tissue engineering applications. The glasses are degradable and can release biologically important ions in a controlled manner. The glasses can also potentially be used as an antimicrobial delivery system. In the given study, novel cobalt doped phosphate-based glasses, $\left(\mathrm{P}_{2} \mathrm{O}_{5}\right)_{50}\left(\mathrm{Na}_{2} \mathrm{O}\right)_{20}(\mathrm{CaO})_{30-\mathrm{x}}(\mathrm{CoO})_{\mathrm{x}}$ where $0 \leq \mathrm{x}$ $(\mathrm{mol} \%) \leq 10$, were manufactured and characterised. As the cobalt oxide concentration increased the rate of dissolution was observed to decrease. The antimicrobial potential of the glasses was studied using direct and indirect contact methods against both Escherichia coli (NCTC 10538) Staphylococcus aureus (ATCC 6538) and Candida albicans (ATCC 76615). The results showed a strong, time dependent and strain specific, antimicrobial activity of the glasses against microorganisms when in direct contact. Antimicrobial activity $(\mathrm{R}) \geq 2$ was observed within 2 hours against Escherichia coli whereas similar effect was achieved in 6 hours against Staphylococcus aureus and Candida albicans. However, when in indirect contact, the dissolution products from the bioactive glasses failed to show antimicrobial effect. Following direct exposure to the glasses for 7 days, osteoblast-like SAOS-2 cells showed a 5-fold increase in VEGF mRNA whilst THP-1 monocytic cells showed a 4-fold increase in VEGF mRNA expression when exposed to $10 \% \mathrm{CoO}$ doped glass compared with the cobalt free control glass. Endothelial cells stimulated with conditioned medium taken from cell cultures of THP-1 monocytes exposed to $10 \% \mathrm{CoO}$ doped glass showed clear tube-like structure (blood vessel) formation after 4 hours.
\end{abstract}

\title{
1. Introduction
}

The growth and attachment of bacteria on surfaces leads to contamination and/or infections [1], therefore prevention of microbial adhesion and colonisation is the preeminent strategy to combat infections. In the last few decades a number of antimicrobial surfaces have been developed such as antibacterial plastics, ceramics and clothes [2-4] to prevent microbial colonisation. Likewise, recent attempts to coat or impregnate medical devices, such as urinary and central venous catheters, ventilators, dental and orthopaedic implants, with antimicrobials are gaining interest [5-7]. However, 
lack of antimicrobial activity and/or failure in the delivery system highlights the need to improve the properties of existing materials.

Bioactive glasses show great potential for a range of hard and soft tissue bioengineering applications [8-10]. These biodegradable glasses can be tailored to provide a controlled release of ions (e.g. Ca and $\mathrm{P}$ ) to stimulate the desirable cellular responses. In addition, antimicrobial metallic ions such as $\mathrm{Ag}, \mathrm{Cu}$ or $\mathrm{Zn}$ can also be incorporated to reduce infections. The degradation rate of phosphate-based glasses can be tailored by several orders of magnitude by changing the glass composition making it an ideal controlled delivery system of antimicrobial ions. Consequently silver and copper doped bioactive glasses have been widely studied for their broad and strong antimicrobial properties $[4,11$ 15]. Silver doped bioactive glasses have shown bacteriostatic and bactericidal properties against Escherichia coli, Pseudomonas aeruginosa, and Staphylococcus aureus. Knowles et al. investigated the antimicrobial effect of silver-doped phosphate-based glass on planktonic bacteria as well as the effect of increasing copper content in phosphate based glasses on biofilms of Streptococcus sanguis $[13,15]$. Although silver and copper doped glasses have been report to exhibit moderate antimicrobial properties, recent studies have documented emergence of resistance [16, 17]. Therefore, the emerging resistance not only calls for development of new antimicrobial agents but also better delivery devices for delivering lethal doses effective against microorganisms.

Recently cobalt has been incorporated into bioactive glasses to help promote vascularisation [18, 19]. Cobalt ions are known to activate the hypoxia pathway by stabilising the Hypoxia Inducible Factor$1 \alpha($ HIF-1 $\alpha)$ transcription factor [20-22]. Studies have shown that bioactive glasses can be tailored to release $\mathrm{Co}^{2+}$ ions within the biologically active concentration range (10-14 ppm) without being cytotoxic $[23,24]$. However, to date the antimicrobial activity of cobalt doped glasses has not been studied. The present study therefore investigates the antimicrobial efficacy of a range of novel cobalt doped phosphate-based glasses against clinically relevant gram positive, gram negative and fungal microorganism: Escherichia coli, Staphylococcus aureus and Candida albicans. 
Previous studies have demonstrated that the methodology (direct / indirect studies) can have a significant impact of the resulting antimicrobial activity [25]. The present study therefore aims to determine the antimicrobial efficacy for a series of cobalt containing glasses for a range of potential biomedical applications by employing both the direct contact and indirect contact methodologies using the international standards (ISO-22196).

\section{Methods and Materials}

2.1 Glass preparation: Glasses were prepared using the melt quench method with $\mathrm{NaH}_{2} \mathrm{PO}_{4}$ (>99.0\%, Sigma Aldrich, Dorset, UK), $\mathrm{P}_{2} \mathrm{O}_{5}$ (99\%, Fisher Scientific) and $\mathrm{CaCO}_{3}(99.95 \%$, Alfa Aesar, Lancashire, UK) as starting materials. To produce cobalt containing phosphate-based glasses $\mathrm{CoO}(99 \%$, Sigma Aldrich, Dorset, UK) was used. The glasses manufactured had fixed concentrations of $\mathrm{P}_{2} \mathrm{O}_{5}(50 \mathrm{~mol} \%)$ and $\mathrm{Na}_{2} \mathrm{O}(20 \mathrm{~mol} \%)$ with the remaining $30 \%$ composed of $\mathrm{CaO}(30-\mathrm{x})$ and $\mathrm{x}$ CoO as shown in Table 1.

Table 1: nominal compositions of the glasses investigated.

\begin{tabular}{ccccc}
\hline & \multicolumn{4}{c}{ Concentration (Mol \%) } \\
\hline Glass code & $\mathrm{P}_{2} \mathrm{O}_{5}$ & $\mathrm{CaO}$ & $\mathrm{Na}_{2} \mathrm{O}$ & $\mathrm{CoO}$ \\
\hline 0 & 50 & 30 & 20 & 0 \\
$1 \%$ & 50 & 29 & 20 & 1 \\
$3 \%$ & 50 & 27 & 20 & 3 \\
$5 \%$ & 50 & 25 & 20 & 5 \\
$10 \%$ & 50 & 20 & 20 & 10 \\
\hline
\end{tabular}

Starting reagents were carefully weighed out $( \pm 1.0 \mathrm{mg})$ and then thoroughly mixed before placing into a $59 \mathrm{ml}$ 90\% Pt -10\% Rh crucible (GLC alloys Ltd Middlesex, UK). The crucible was placed in a chamber furnace at room temperature and then heated up to $300^{\circ} \mathrm{C}$ at a rate of $10^{\circ} \mathrm{C}$ per minute. After one hour the temperature was rapidly increased to $600^{\circ} \mathrm{C}$ and the sample was held at this 
temperature for a further 30 minutes, the temperature was then rapidly increased up to $1050^{\circ} \mathrm{C}$ and held at this temperature for 30 minutes. The molten glass was poured into a split graphite mould, with $10 \mathrm{~mm}$ aperture, which had been preheated at $350^{\circ} \mathrm{C}$. The glass samples were annealed overnight at $350^{\circ} \mathrm{C}$ and then slowly cooled to room temperature in the graphite mould to produce glass rods. These rods were cut into $2 \mathrm{~mm}$ thick discs using an IsoMet ${ }^{\mathrm{TM}} 1000$ Precision saw (Buehler). Discs were polished using MetaServ ${ }^{\circledR}$ (Buehler) polishing machine using a series of polishing clothes $(30 \mu, 15 \mu$ using lapping oil) followed by a final polish using $0.02 \mu$ colloidal silica. The discs were cleaned in acetone and air dried. Prior to undertaking the experiments, the discs were sterilised using dry heat at $180^{\circ} \mathrm{C}$ for 2 hours. Samples were stored in a desiccator between stages of preparation to reduce exposure to atmospheric moisture.

X-ray diffraction data were collected at I-15 beamline, Diamond Light Source, Harwell, UK. The instrument was set up to collect data in a $2 \theta$ geometry with an incident energy of $76.7 \mathrm{KeV},(\lambda=$ $0.162 \AA$ ). Glass samples were ground into fine powders and loaded into $1.17 \mathrm{~mm}$ internal diameter, $1.5 \mathrm{~mm}$ outer diameter x $40 \mathrm{~mm}$ glass capillaries and all measurements carried out at room temperature. An empty capillary was measured for background corrections. Data corrections including background, normalisation, attenuation, absorption, Compton scattering, x-ray beam polarisation, Bremsstrahlung, fluorescence and subtraction of self-scattering term which were performed using a program GUDRUNX [26].

2.2 Degradation study: cobalt oxide doped phosphate-based glass discs (radius $10 \mathrm{~mm}$ and $\sim 2 \mathrm{~mm}$ thickness) containing different cobalt content were placed in $60 \mathrm{ml}$ plastic containers (Fisher Scientific, Loughborough, Leicestershire) filled with $25 \mathrm{ml}$ of standard distilled water. The containers were then placed in a $37^{\circ} \mathrm{C}$ incubator at $200 \mathrm{rpm}$. Weight loss measurements were taken at 24-hour intervals for 7 days. Glass discs were removed from their respective containers and excess moisture was removed by tissue prior to taking weight measurement. To determine the degradation rate, weight loss was calculated using 


$$
\text { Weight loss }=\left(\mathrm{M}_{0}-\mathrm{M}_{t}\right) / \mathrm{A}
$$

where $\mathrm{M}_{0}$ is initial weight in $\mathrm{mg}, \mathrm{M}_{t}$ is weight in $\mathrm{mg}$ at time $t$ and $\mathrm{A}$ is the surface area, $\mathrm{cm}^{2}$, of the original disc. Only a single time point was recorded per disc.

Weight loss was plotted against time and the slope of the graph gave a degradation value $\left(\mathrm{mg} \mathrm{cm}^{-2} \mathrm{~d}^{-}\right.$ $\left.{ }^{1}\right)$. Degradation analysis was also conducted in nutrient broth which was used for the antimicrobial studies. Each measurement was carried out in triplicate.

$2.3 \mathrm{pH}$ analysis: $\mathrm{pH}$ measurements of the degradation media were simultaneously taken at every time point using $\mathrm{pH}$ meter (Mettler Toledo, Switzerland). Three-point calibration of the $\mathrm{pH}$ electrode was achieved using pH calibration standards (Fisher Scientific, Loughborough, UK).

2.4 Ion release study: The media obtained at each time point from degradation studies in distilled water was analysed for the presence of cations $\left(\mathrm{Na}^{+}, \mathrm{Ca}^{2+}, \mathrm{Co}^{2+}\right)$ and anions $\left(\mathrm{PO}_{4}^{3-}\right)$ using inductively coupled plasma optical emission spectrometry, ICP-OES (iCAP ${ }^{\mathrm{TM}} 7000$ Plus Series). The dissolution products were filtered prior to measurements using $0.2 \mu \mathrm{m}$ Ministart filters (Fisher Scientific, UK) and the concentration of each ion was calculated from the linear portion of the generated standard curve as ppm.

2.5 Cell culture studies: The human monocytic cell line THP-1 and human osteosarcoma cell line SAOS-2 were obtained from ECACC and cultured as recommended, in RPMI 1640 (containing 10\% Fetal Calf Serum) and McCoy's 5a medium (15\% FCS), respectively, containing 2 mM L-glutamine (Life Technologies, Paisley, UK), $200 \mathrm{U} / \mathrm{ml}$ penicillin/200 $\mu \mathrm{g} / \mathrm{ml}$ streptomycin (Life Technologies). Glasses were ground in a pestle and mortar, sieved to achieve a particle size range of 75-125 microns, baked at $250^{\circ} \mathrm{C}$ for 1 hour to sterilise and to destroy adherent endotoxin, then added to the appropriate volume of serum-free RPMI 1640 medium (Sigma). For gene expression analysis, THP-1 cells and SAOS-2 cells were cultured in RPMI 1640 or McCoy's 5a medium, respectively, containing 2\% Fetal Calf Serum, 2mM L-glutamine, $200 \mathrm{U} / \mathrm{ml}$ penicillin, and $200 \mu \mathrm{g} / \mathrm{ml}$ streptomycin (Life Technologies). Cells were exposed to bioactive glasses at a concentration of $0.5 \mathrm{mg} / \mathrm{mL}$ for 7 days 
before cells were collection and lysed in Tri Reagent (Sigma) for RNA extraction. For medium conditioning studies prior to angiogenesis assays, glasses were added at a concentration of $0.25 \mathrm{mg} / \mathrm{ml}$ to cells of the human macrophage cell line THP-1. Cells were seeded in RPMI 1640 medium containing $2 \mathrm{mM}$ L-glutamine, $200 \mathrm{U} / \mathrm{ml}$ penicillin, $200 \mu \mathrm{g} / \mathrm{ml}$ streptomycin, and 1\% Fetal Calf Serum, at a density of $2 \times 10^{5}$ cells per $\mathrm{ml}$, in 6 well plates, with a volume of $2 \mathrm{ml}$ per well. Conditioned medium samples for use in angiogenesis assays were taken after $20 \mathrm{hrs}$ exposure of cells to glass suspensions.

2.6. Angiogenesis assays were carried out using placental Human Umbilical Vein Endothelial Cells (HUVEC) and associated reagents from Life Technologies (Thermo Fisher, UK) following the manufacturer's protocols. HUVEC cells are able to form blood vessel-like tubular structures within 3-4 hrs of being seeded at a density of $4 \times 10^{4}$ cells per well of a 24 well plate in a volume of $400 \mu \mathrm{L}$ of Medium 200 PRF (Life Technologies) in the presence of angiogenic factors such as Vascular Endothelial Growth Factor (VEGF). Wells were coated with $100 \mu \mathrm{L}$ of GelTrex extracellular matrix (Life Technologies) for 30 mins at $37^{\circ} \mathrm{C}$ prior to addition of HUVEC cells. Addition of $2 \%$ Life Technologies Low Serum Growth Supplement, which contains known concentrations of proangiogenic factors, was used as the positive control. Other wells were treated with $5 \mu \mathrm{L}$ of conditioned medium taken from THP-1 cells exposed to bioactive glasses for $20 \mathrm{hrs}$ as described above. After 3.5hrs incubation the cell permeant fluorescent dye Calcein AM (Life Technologies), which stains live cells, was added to a final concentration of $1 \mu \mathrm{M}$ for 30 mins before brightfield and fluorescence microscopy.

2.7 RNA extraction and Real-Time RT-PCR: RNA was extracted using Tri Reagent (Sigma) according to the manufacturer's instructions. Reverse transcription, gene specific primers for Vascular Endothelial Growth Factor (VEGF) and the housekeeping gene Beta-2 microglobulin (B2m), and PCR normalisation procedures, were as we previously described [27]. Real-Time PCR 
was performed using a 96 well plate Roche Light Cycler 480 instrument, using Roche reagents as recommended by the manufacturer. PCRs were performed in triplicate using $45 \mathrm{x}: 95^{\circ} \mathrm{C} 10 \mathrm{sec}, 60^{\circ} \mathrm{C}$ $10 \mathrm{sec}, 72^{\circ} \mathrm{C} 20 \mathrm{sec}$.

2.8 Antimicrobial studies: cobalt doped phosphate-based glasses were investigated for their ability to inhibit or kill microorganisms via direct and indirect contact methods. Two bacterial strains; Escherichia coli (NCTC 10538), Staphylococcus aureus (ATCC 6538) and a fungal strain, Candida albicans (ATCC 76615) were used in this study. These strains were maintained at $-80^{\circ} \mathrm{C}$ on MicroBank beads (Pro-Lab Diagnostics Neston, Cheshire, UK). Escherichia coli and Staphylococcus aureus were cultured in nutrient broth/agar and incubated at $37^{\circ} \mathrm{C}$ whereas Candida albicans was maintained in Sabouraud dextrose broth/agar at $30^{\circ} \mathrm{C}$.

The antimicrobial efficacy of the cobalt doped glass discs was studied using direct (film contact method, ISO-22196) and indirect method (effect of dissolution products from glasses).

2.8.1 Evaluation of antimicrobial activity of glass surfaces: To determine the antimicrobial potential of the different glass surfaces, the international standard protocol for testing non-porous surfaces; ISO-22196 was used [28]. To conduct experiments, an overnight microbial culture was adjusted, using fresh nutrient or Sabouraud dextrose broth depending upon the microbial strain, to produce $\sim 10^{6} \mathrm{CFU}$ microbial density on the top surface of the glass discs. A thin sterile glass cover slip (Fisher Scientific, UK) was placed on the top of the inoculum and pressed gently so that the test inoculum spreads to the edges. The cover slip not only helps to create a thin bacterial film on the glass discs but also prevents the bacterial death due to desiccation. Inoculated glass discs were then placed in a Petri dish and incubated at $37^{\circ} \mathrm{C}$ and $30^{\circ} \mathrm{C}$. Standard plastic coverslips with $12 \mathrm{~mm}$ diameter were used as the control. At each time point; 2, 4, 6 and 24 hours three glass discs were removed from each set of glass composition along with control plastic coverslips and washed with $5 \mathrm{ml}$ of D/E broth (Becton Dickinson UK Ltd). This was achieved by placing the test glass discs in $5 \mathrm{ml} \mathrm{D} / \mathrm{E}$ broth and vortexing for two minutes. The viable bacterial count in the broth was determined by the spread plate 
method[29]. In addition, immediately after inoculation, untreated test specimens were processed, and the viable count determined was used as the recovery rate of the microorganisms from the test specimens under investigation.

The antibacterial effect was evaluated according to the standard outlined in ISO-standard 222196. The number of viable bacteria, $\mathrm{N}$, for each specimen was determined using

$$
\mathrm{N}=(100 \times \mathrm{C} \times \mathrm{D} \times \mathrm{V}) / \mathrm{A}
$$

where $\mathrm{C}$ is the average plate count, $\mathrm{D}$ is the dilution factor for the plates counted, $\mathrm{V}$ is the volume in $\mathrm{ml}$ of $\mathrm{D} / \mathrm{E}$ broth and $\mathrm{A}$ is the surface area of the cover film.

The antibacterial activity, $\mathrm{R}$, was determined using

$$
\mathrm{R}=\left(\mathrm{U}_{t}-\mathrm{U}_{0}\right)-\left(\mathrm{A}_{t}-\mathrm{U}_{0}\right)=\mathrm{U}_{t}-\mathrm{A}_{t}
$$

where $\mathrm{U}_{0}$ and $\mathrm{U}_{t}$ are the average of the common logarithm of the number of viable microorganisms, in cells $/ \mathrm{cm}^{2}$ recovered from the untreated test specimens immediately after inoculation $(t=0)$ and at time $t$ respectively; and $\mathrm{A}_{t}$ is the average of the common logarithm of the number of viable microorganisms, in cells.cm-2 recovered from the treated test specimens after time $t$.

2.8.2 Effect of dissolution products from the glasses on microbial growth: In this method sterilised glass discs were placed in $25 \mathrm{ml}$ of nutrient broth containing $10^{6} \mathrm{CFU} / \mathrm{ml}$ of the microbial culture. The test samples along with control (broth without glass discs) were then incubated in an aerobic incubator at $37^{\circ} \mathrm{C}\left(30^{\circ} \mathrm{C}\right.$ for Candida albicans $)$ with a shaking speed of $200 \mathrm{rpm}$. At various time intervals; 24, 48, 72, 96 and 120 hours, a $100 \mu 1$ sample was taken out from each test container and serially diluted to determine the viable count. All experiments were undertaken in triplicate.

2.9 Statistical analysis: Two-way analysis of variance was carried out to determine statistical significances (GraphPad Prism 7.0). If a significant difference was detected a Tukey test was carried 
out to determine which values were significantly different. Differences were considered statistically significantly at a level of $P<0.05$.

\section{Results}

3.1 Glass manufacture and degradation: a series of cobalt oxide doped glasses were successfully prepared. The glasses were fully amorphous with no visible signs of Bragg peaks as shown in Figure 1. A linear increase in weight loss as a function of time was observed for all samples as shown in Figure 2. As can be seen the weight loss decreased with increasing cobalt oxide content of the glass, i.e. the control glass $(0 \% \mathrm{Co})$ has the largest weight loss whereas $10 \mathrm{~mol} \%$ Co showed least solubility. The dissolution rates by applying line of best fit through the data were 5.3, 3.8, 2.6, 2.3 and $1.4 \mathrm{mg} \cdot \mathrm{cm}^{-2}$.day ${ }^{-1}$ for $0,1,3,5$ and $10 \mathrm{~mol} \%$ Co doped glasses respectively. The general glass dissolution trend, decreasing dissolution with an increasing cobalt oxide content, is the same for both distilled water and nutrient broth. However, it is clear that the rate of degradation is strongly dependant on the media used. The dissolution rates in standard distilled water (which are usually quoted) were approximately twice as high compared to when the samples were placed in nutrient broth. For instance, the degradation value at day 7 for $1 \%$ cobalt glass in distilled water was $27 \mathrm{mg} \cdot \mathrm{cm}^{-2}$ whereas the degradation rate was $14 \mathrm{mg} \cdot \mathrm{cm}^{-2}$ in nutrients broth.

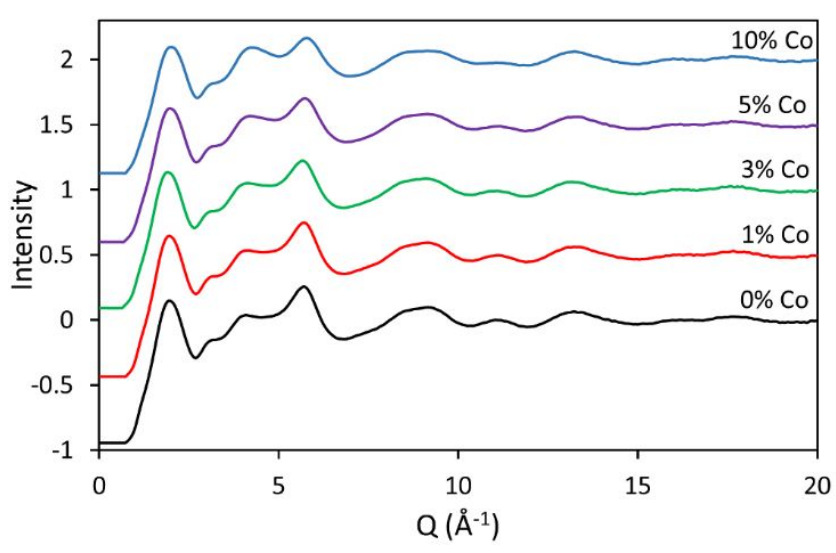

Figure 1. X-ray diffraction spectra, illustrating the absence of Bragg peaks. 

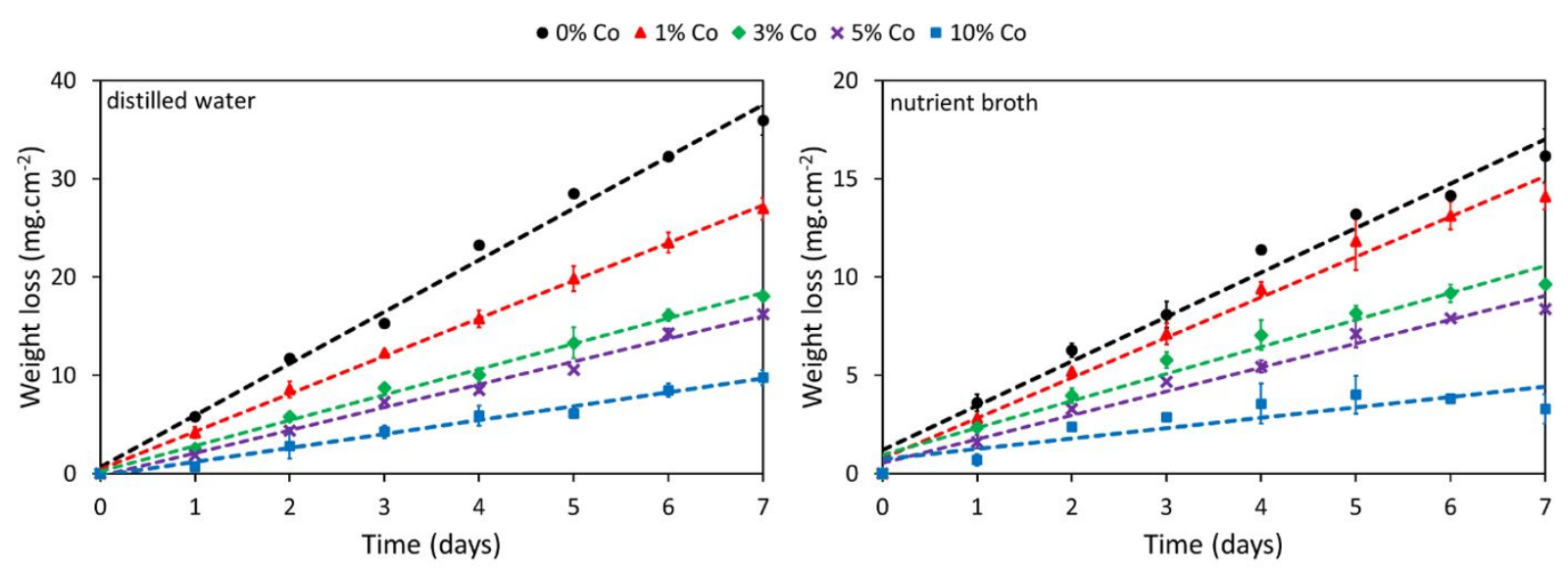

Figure 2: The degradation profiles obtained for $0,13,5$ and $10 \mathrm{~mol} \% \mathrm{CoO}$ compositions, investigated in distilled water and nutrient broth. Error bars $= \pm$ SD for triplicate samples.

The rate of weight loss as a function of cobalt oxide concentration approximates an exponential decay curve as shown in Figure 3. It is apparent that the initial additions of small amounts of cobalt oxide (1 and 3\%) have the greatest impact on glass dissolution and weight loss.
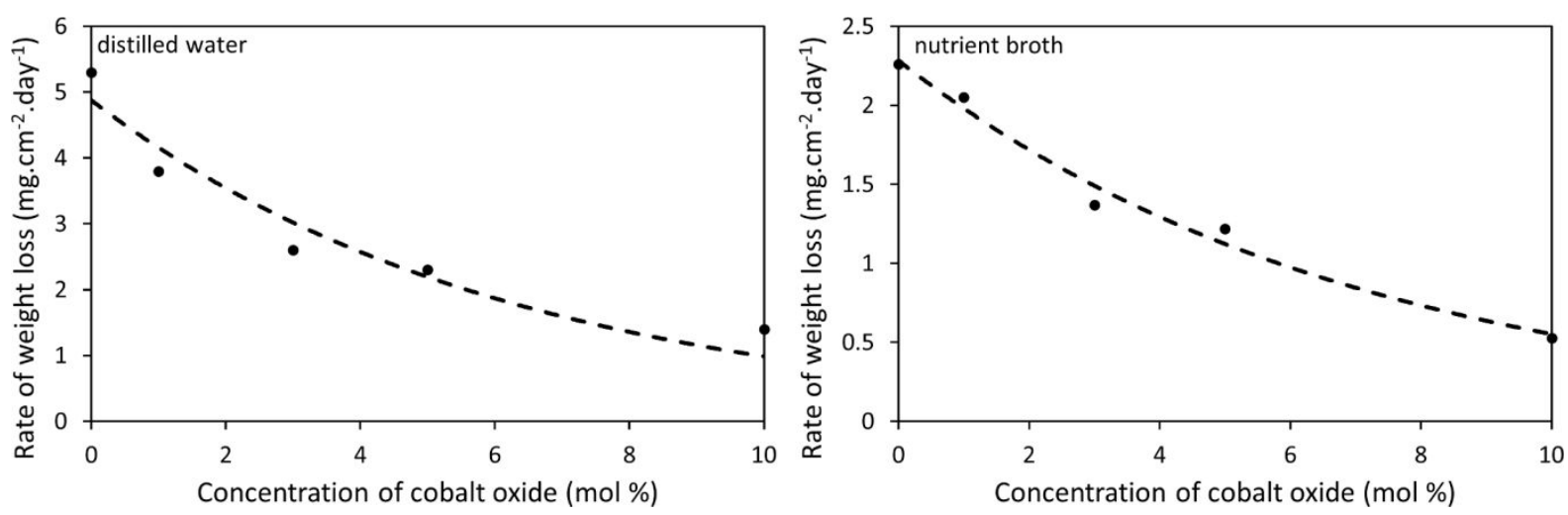

Figure 3. The rate of weight loss of the phosphate glasses as a function of cobalt oxide concentration, when placed in distilled water and nutrient broth.

3.2 pH analysis: A sharp decrease in $\mathrm{pH}$ was observed for all compositions glasses when placed in distilled water. A rapid decrease in $\mathrm{pH}$ was observed within the first 24 hours, where the values dropped from 6.7 to $\sim 3.9-4.5$, before the $\mathrm{pH}$ values began to plateau out as shown in Figure 4 . Cobalt free composition showed the maximum decrease in the $\mathrm{pH}$ value followed by $1 \mathrm{~mol} \%$ cobalt glass whilst the $10 \%$ cobalt glass showed the smallest reduction in $\mathrm{pH}$. These values are consistent with the weight loss measurements shown in Figure 2. In contrast the $\mathrm{pH}$ of nutrient broth remained in the optimum range for the duration of the study between 6.3 and 6.7. Given that the weight loss in nutrient broth is approximately half of that observed in distilled water in may be anticipated that the 
$\mathrm{pH}$ would drop significantly over the first 48 hours. However, it is clear that the broth has a strong buffering effect on the $\mathrm{pH}$.
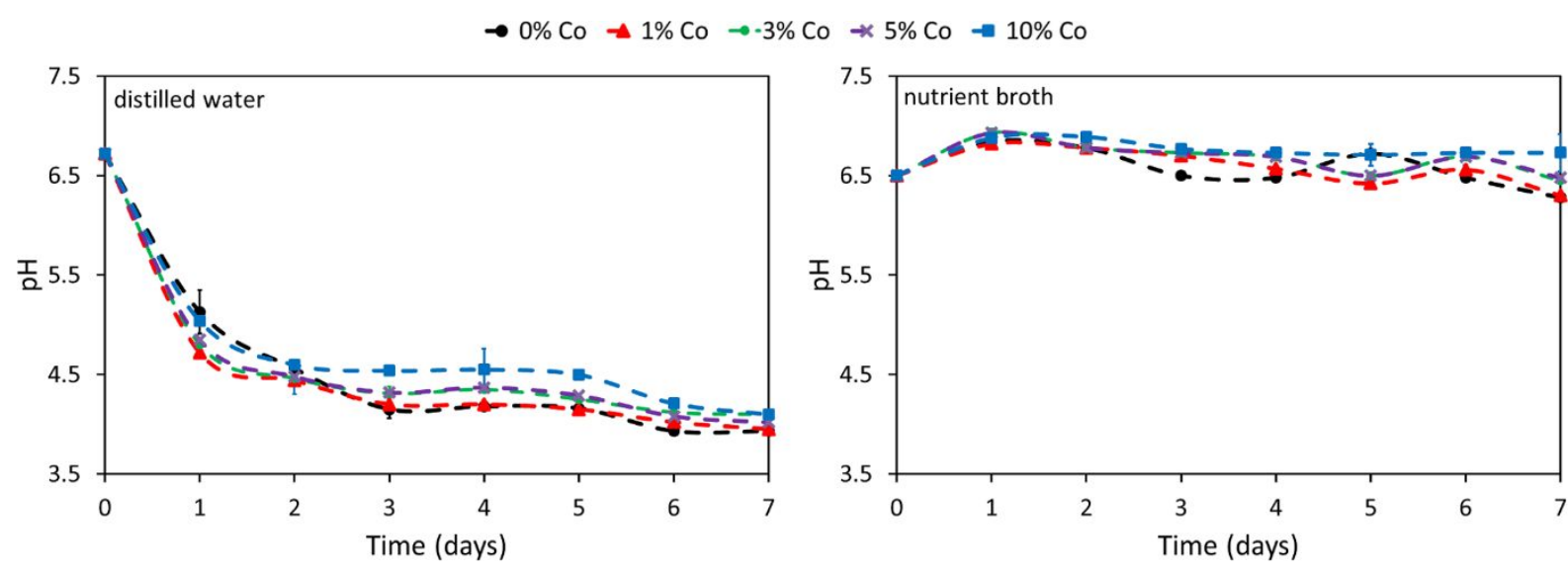

Figure 4. Resultant $\mathrm{pH}$ as a function of time for distilled water and nutrient broth containing cobalt doped phosphate glasses.

3.3 ICP-OES: The ion release analysis performed in deionised water over a seven-day period is shown in Figure 5. A linear increase in the release of both anions $\left(\mathrm{PO}_{4}^{3-}\right)$ and cations $\left(\mathrm{Ca}^{2+}\right.$ and $\left.\mathrm{Na}^{+}\right)$ was observed for all compositions over the timeframe investigated. The ion release kinetics revealed an inverse relationship between overall ion release rate and glass Co content, consistent with the findings from the weight loss profiles. $\mathrm{Co}^{2+}$ release rates $\left(\left[\mathrm{Co}^{2+}\right]\right)$ were observed to be proportional with glass Co content when normalised for the rate of weight loss/solubility of the glass. This suggests the dominating parameter affecting $\left[\mathrm{Co}^{2+}\right]$ from these composite materials be glass Co content although the weight loss also plays a significant role. 

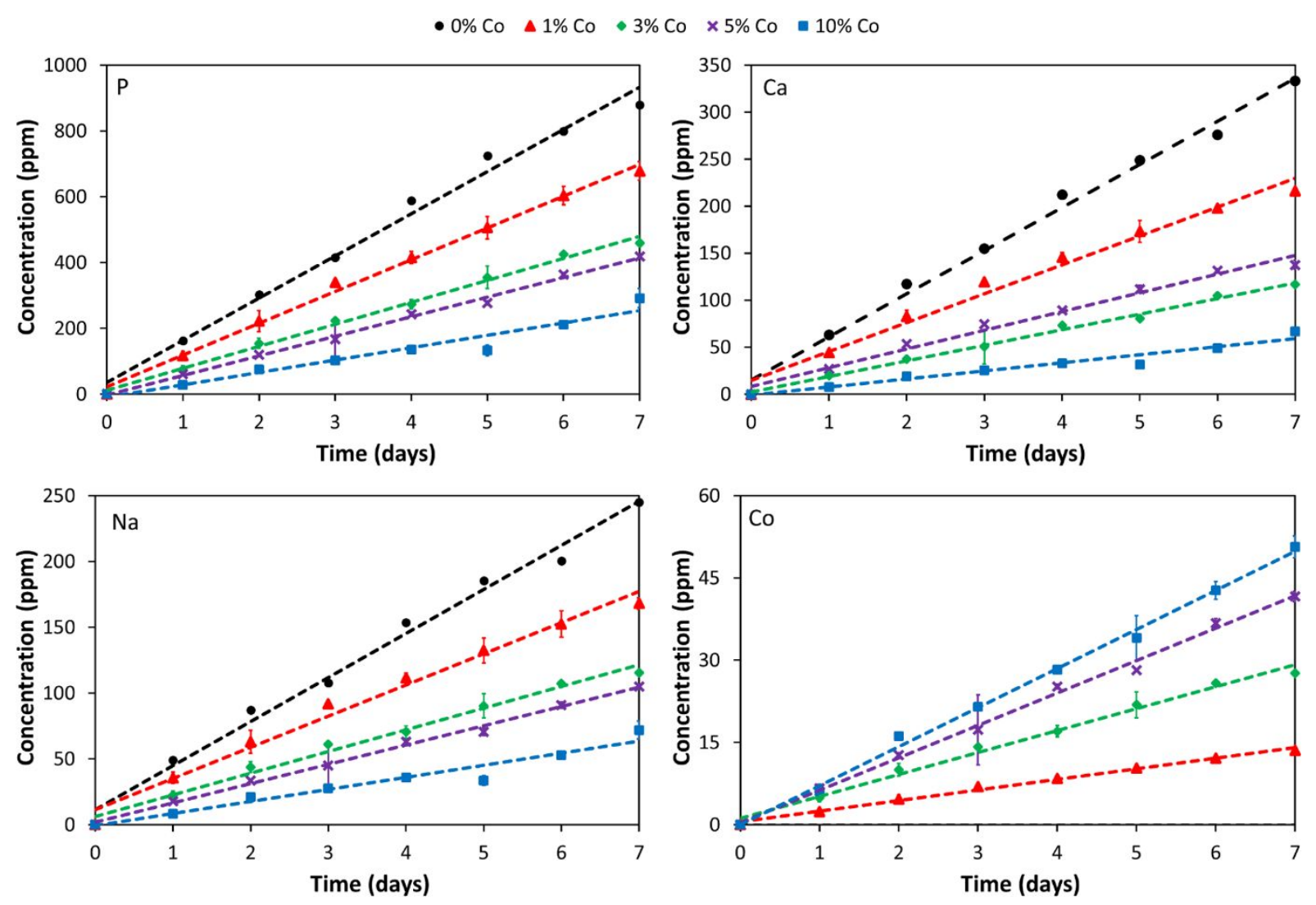

Figure 5: Accumulative ion release phosphorous, calcium, sodium and cobalt as a function of time for $0,1,3,5$ and $10 \mathrm{~mol} \%$ cobalt doped glasses. (Error bars $= \pm \mathrm{SD}$ for triplicate samples).

\subsection{Evaluation of the VEGF mRNA expression}

The relative mRNA expression levels for the pro-angiogenic cytokine Vascular Endothelial Growth Factor (VEGF) in the human SAOS-2 (osteosarcoma) and THP-1 (monocytic) cell lines after 7 days direct exposure to the cobalt free control glass and the $10 \% \mathrm{CoO}$ glass are shown in Figure 6 . Untreated was the negative control. At 7 days the $10 \% \mathrm{CoO}$ doped phosphate glass produced a 5-fold increase in mean VEGF mRNA expression in SAOS-2 when compared with the cobalt free glass and the untreated cells. A 4-fold increase in mean VEGF mRNA expression in THP-1 macrophages was observed after 7 days compared with the cobalt free glass and the untreated cells. One-way ANOVA and Tukey's multiple comparisons test was conducted to test for significance; data are presented as mean \pm SD. Significance was set at $\mathrm{p} \leq 0.05, \mathrm{~N}=3$. 
No significance was detected between the untreated and the $0 \%$ Co free phosphate glass samples. The $10 \% \mathrm{CoO}$ showed a significant increase compared to both the untreated and $0 \% \mathrm{CoO}$ controls $(\mathrm{p}<$ $0.0001)$.
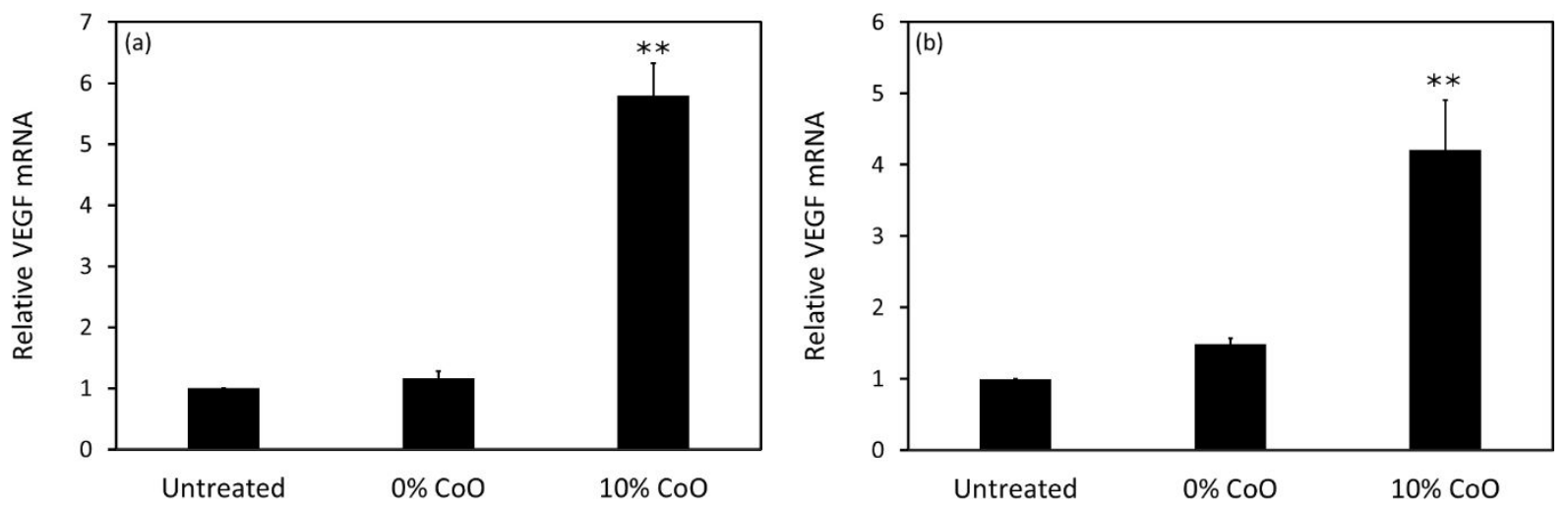

Figure 6. Relative VEGF mRNA expression for (a) SAOS-2 cells and (b) THP-1 cells.

Figure 7 shows the overlaid fluorescent and brightfield images of primary human umbilical vein endothelial cells (HUVEC) stimulated with media extracted from cell culture of THP-1 monocytes exposed to 0 and $10 \% \mathrm{CoO}$ doped phosphate glasses for 1 day. For the positive control it is clear that tube-like (blood vessel) structures are beginning to form. In contrast for the negative control and the $0 \% \mathrm{CoO}$ control phosphate glass no tubule like structures are visible. For the $10 \% \mathrm{CoO}$ doped glass tubule structures similar to the positive control are observed. 


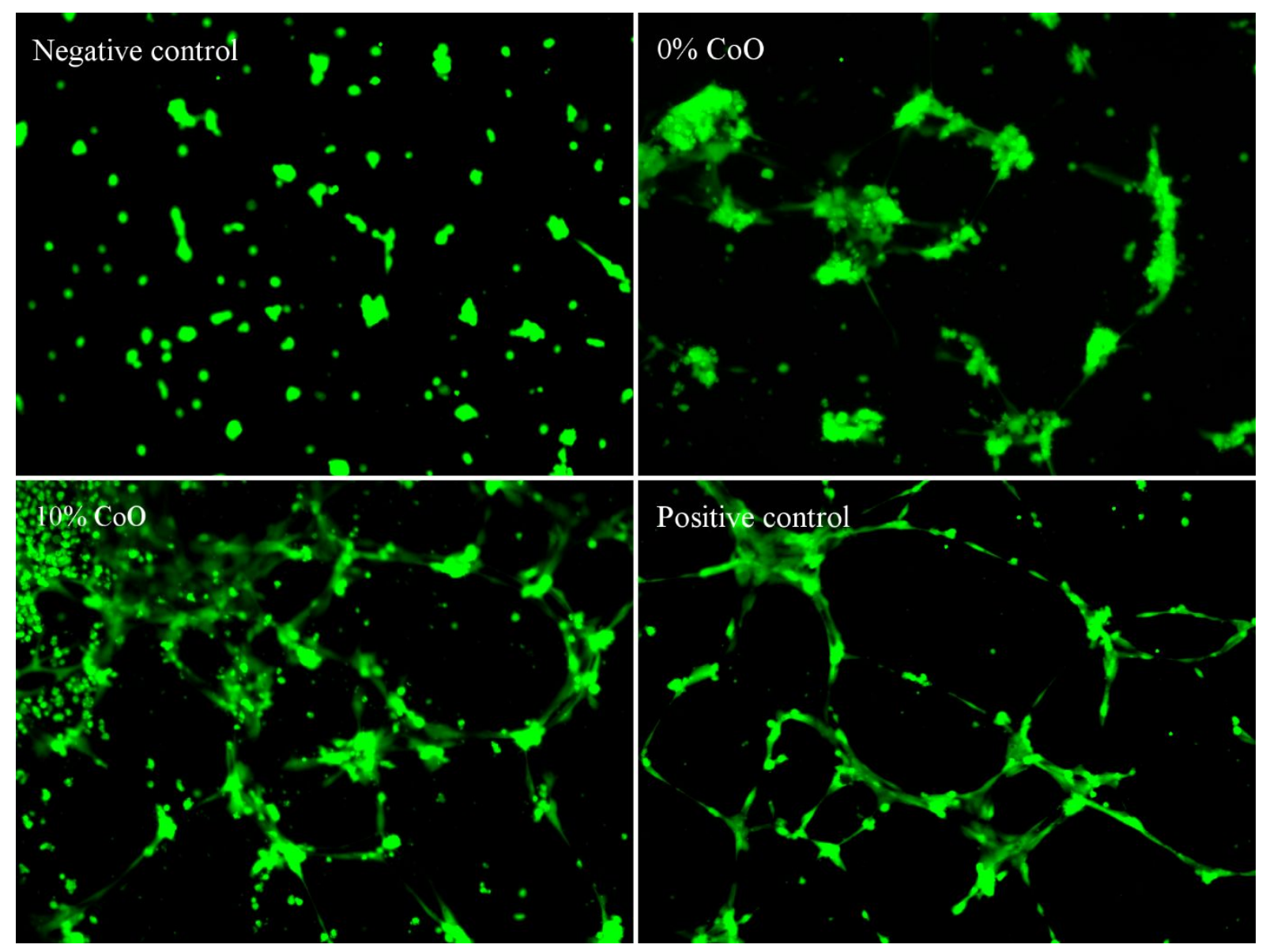

Figure 7. Overlaid fluorescent and brightfield images of endothelial cells stimulated for 4 hours with medium extracted from cell cultures of untreated THP-1 monocytes (negative control), or with medium from THP-1 cells treated with $0 \%$ or $10 \% \mathrm{CoO}$ doped phosphate glasses for 24 hours. The positive control was treated with known pro-angiogenic factors.

3.5- Evaluation of antimicrobial activity of glass surfaces: Figure 8 show the antimicrobial activity of cobalt doped phosphate glasses against E. coli, S. aureus and C. albicans at 2, 4, 6 and 24-hour time intervals. According the ISO-22196, an antimicrobial activity greater than 2 demonstrates that the test specimen is antimicrobial.

Figure 8 a shows the antimicrobial efficacy of un-doped phosphate glass ( 0 mol \%) and 1, 3, 5 and 10 mol \% cobalt doped phosphate glass against $E$. coli when cultured directly on glasses. The cobalt doped glasses demonstrated a strong antimicrobial activity within 2 hours when compared with nontreated control. At 2, 4 and 6 hour time points, significant differences in R value were observed for 
1, 3, 5 and 10 mol \% cobalt doped phosphate glasses compared to un-doped $(0 \%)$ phosphate glass samples $(\mathrm{p}<0.0001)$

Whilst a sharp increase in the activity was observed against $E$. coli within 2 hours, a gradual increase in antimicrobial activity was seen against $S$. aureus. As seen in figure $8 \mathrm{~b}$, the $\mathrm{R}$ value remained below 2 for the initial 4 hours, but at the 6 hour time point all glass compositions showed an antimicrobial activity $\geq 2$ except for the un-doped phosphate glass, however the difference observed was statistically non-significant. A similar trend in $\mathrm{R}$ value was observed at 24 hours. The $\mathrm{R}$ value of all glass compositions exhibited a non-significant increase when compared to un-doped glass except for $10 \mathrm{~mol} \%$ cobalt doped glass which showed a significant increase in R value when compared with un-doped phosphate glass $(\mathrm{p}<0.001), 1$ and $3 \mathrm{~mol} \%$ cobalt doped glasses $(\mathrm{p}=0.0027, \mathrm{p}=0.0044$ respectively). Overall, whilst $E$. coli showed a higher susceptibility with a complete kill seen within 6 hours, complete killing of $S$. aureus was not seen within 24 hours.

Figure $8 \mathrm{c}$ shows the antimicrobial activity of the glasses against $C$. albicans when inoculated directly on glass discs. The $\mathrm{R}$ value in the first 2 hours remained below 2, however at 4 hours 3,5 and 10 mol $\%$ cobalt doped glasses exhibited an antimicrobial activity $\geq 2$, whereas un-doped glass value was less than 2 highlighting the importance of incorporating antimicrobial ions. A statistically significant difference in the activity was not seen until 6 hours, $10 \mathrm{~mol} \%$ cobalt doped glass showed a strong antimicrobial effect when compared to un-doped phosphate glass $(\mathrm{p}=0.0002)$. A complete kill of $C$. albicans was seen within 24 hours. 


\section{E. coli}
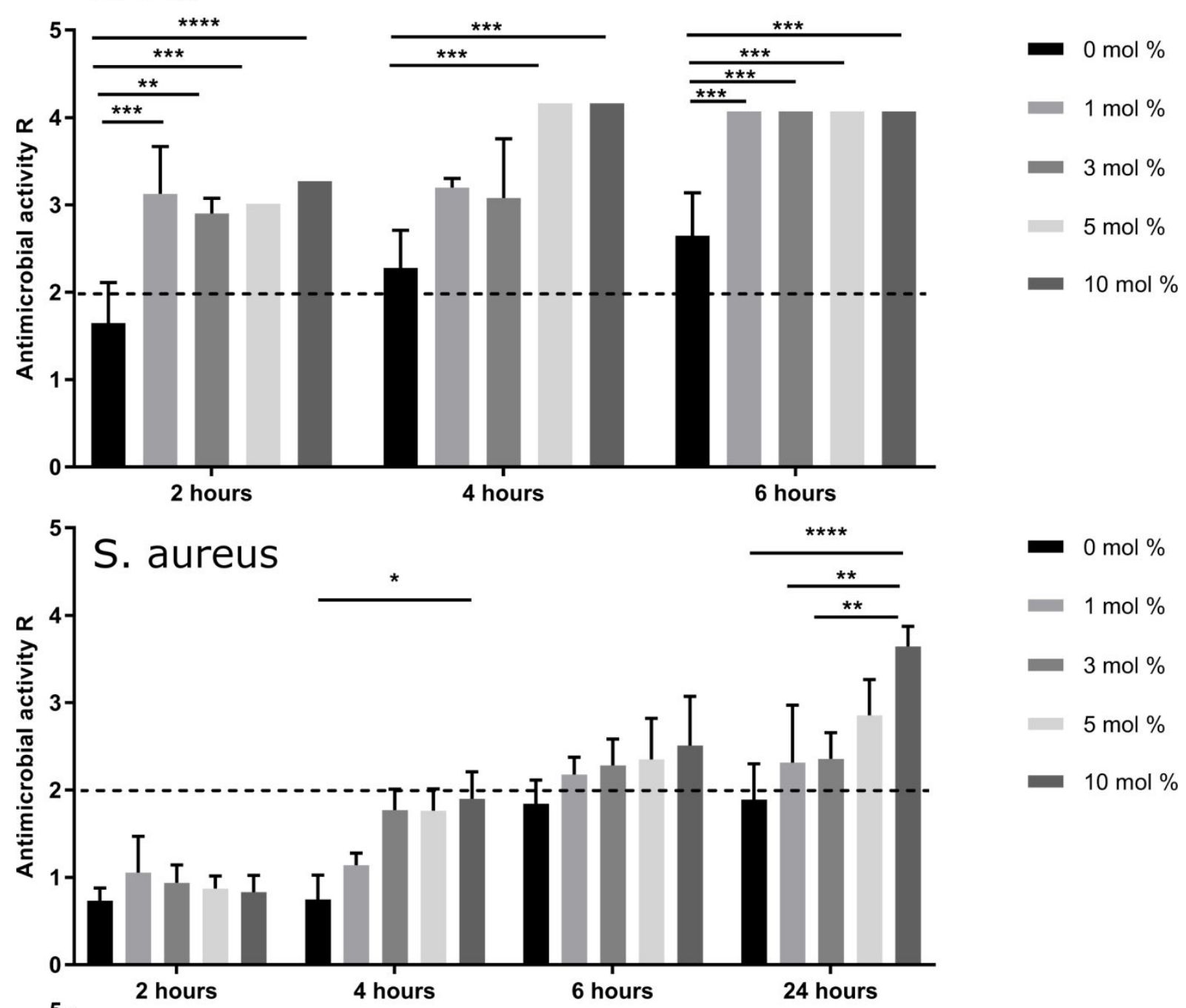

$1 \mathrm{~mol} \%$

$3 \mathrm{~mol} \%$

$5 \mathrm{~mol} \%$

$10 \mathrm{~mol} \%$

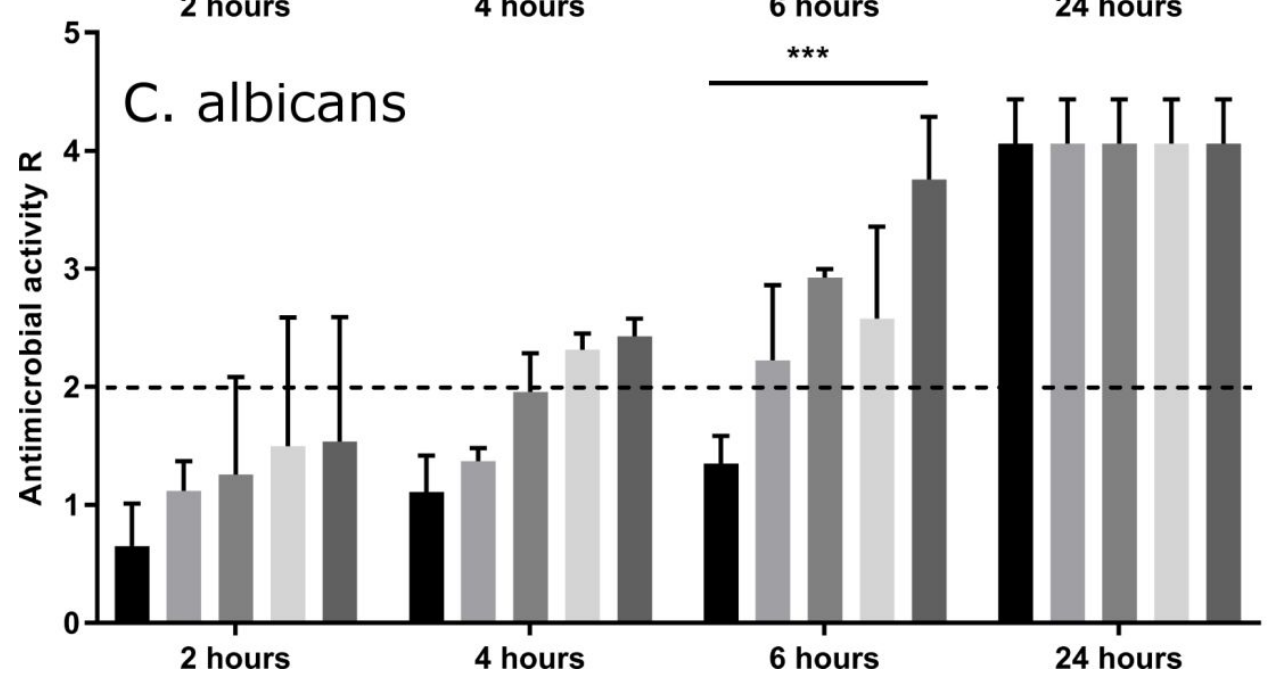

- $0 \mathrm{~mol} \%$

$1 \mathrm{~mol} \%$

$3 \mathrm{~mol} \%$

$5 \mathrm{~mol} \%$

- $10 \mathrm{~mol} \%$

Figure 8: The antimicrobial efficacy of un-doped phosphate glass and 1, 3, 5 and $10 \mathrm{~mol} \%$ cobalt doped phosphate glass against E. coli, S. aureus, C. albicans over a 24 hours period. Data shown are expressed as mean $\pm \mathrm{SD}(\mathrm{N}=3)$ antibacterial activity as determined by ISO-22196.

3.6 Effect of dissolution products of glasses on microbial growth: Figure 9 shows the effect of dissolution products of un-doped and cobalt doped phosphate-based glasses over a 5-day period under 
an aerobic atmosphere at $37^{\circ} \mathrm{C}\left(30^{\circ} \mathrm{C}\right.$ for Candida albicans) and $200 \mathrm{rpm}$ shaking speed. It was observed that the dissolution products of the glasses failed to demonstrate antibacterial effect against E. coli (Figure 9a) over 5 days as the bacterial viability was approximately $100 \%$ when compared with microorganisms cultured in broth only. Similar results were seen against S. aureus (Figure 9b) and C. albicans (Figure 9c). 

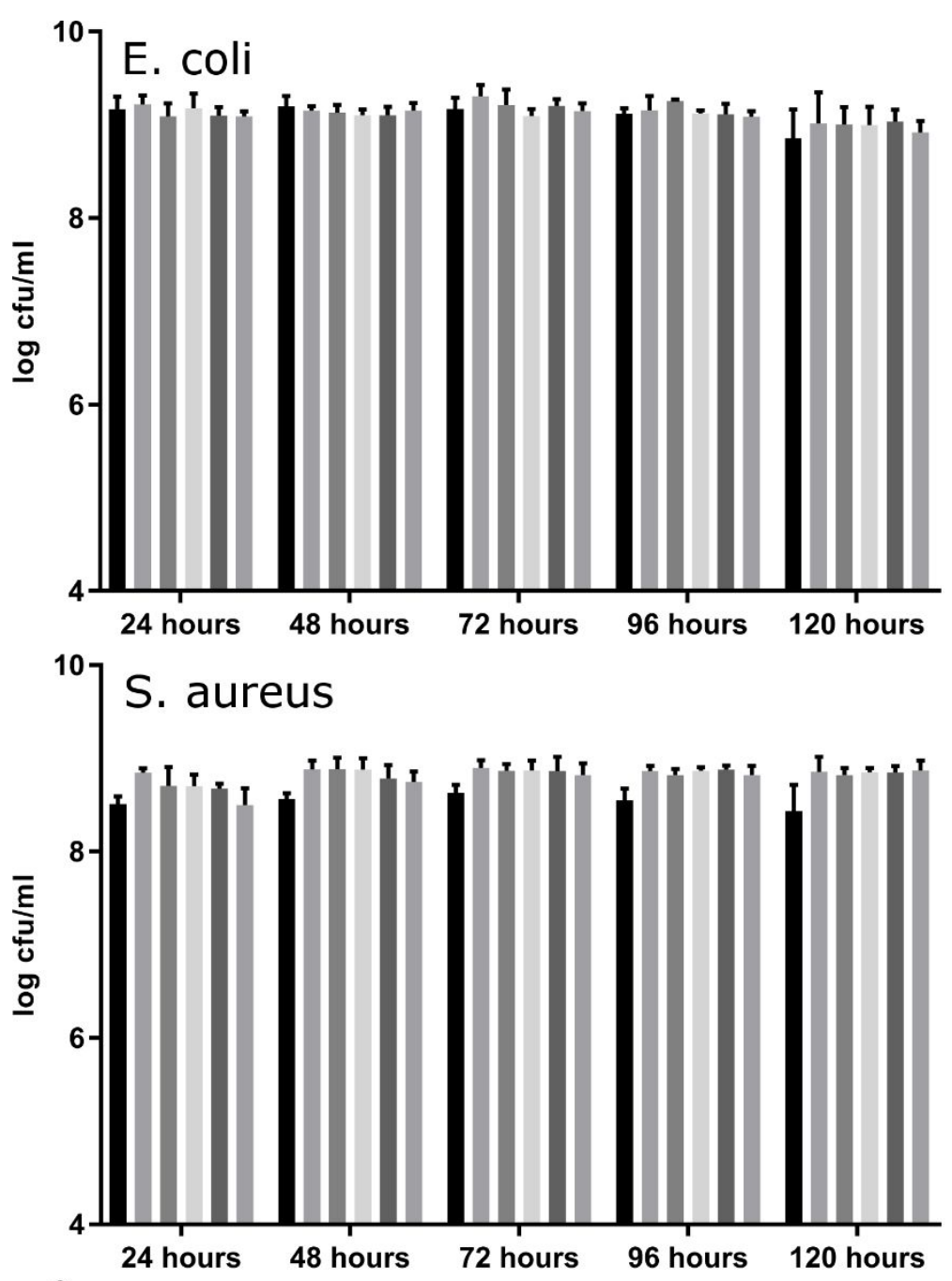

- Control

$0 \mathrm{~mol} \%$

$1 \mathrm{~mol} \%$

$3 \mathrm{~mol} \%$

$5 \mathrm{~mol} \%$

$10 \mathrm{~mol} \%$

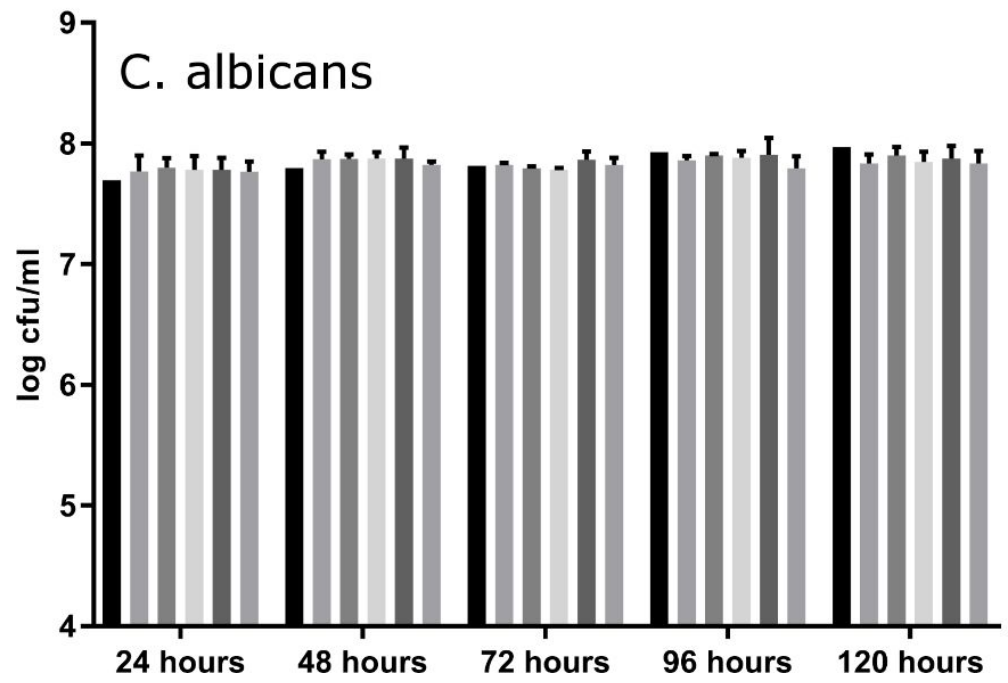

- Control

$0 \mathrm{~mol} \%$

$1 \mathrm{~mol} \%$

$3 \mathrm{~mol} \%$

$5 \mathrm{~mol} \%$

$10 \mathrm{~mol} \%$

Figure 9: The effect of dissolution products of un-doped phosphate glass and 1, 3, 5 and $10 \mathrm{~mol} \%$ cobalt doped phosphate glass against E. coli, $S$. aureus and C. albicans over a 5 days period. Data shown are expressed as mean $\pm \mathrm{SD}(\mathrm{N}=3)$. 


\section{Discussion}

Cobalt doped bioactive glasses have been widely studied as hypoxia mimicking biomaterials for bone tissue regeneration, however, the majority of these studies have been in silicate based glasses [23, 3037]. Whilst many studies have been undertaken to elucidate the antimicrobial potential of various metal doped silicate and phosphate glass systems, to date none of the studies have evaluated the antimicrobial potential of cobalt doped bioactive glasses. The present study, therefore investigated the antimicrobial effect of an un-doped and doped (1, 3, 5 and $10 \mathrm{~mol} \%$ cobalt oxide) phosphate based bioactive glass $\left(\mathrm{P}_{2} \mathrm{O}_{5}-\mathrm{Na}_{2} \mathrm{O}-\mathrm{CaO}\right)$ against clinically important microorganisms.

A decrease in dissolution of cobalt doped glasses was observed with an increasing cobalt oxide content at the expense of calcium oxide. The observed trend in dissolution pattern fits well with the literature available, several studies have demonstrated that the addition of metallic species decrease glass dissolution with an increasing metal oxide content $[11,12,38]$. The dissolution of metaphosphate glasses is mainly controlled by the bonding of the phosphate chains to the modifier atoms [39]. Since the ionic radius of cobalt is smaller than that of calcium, i.e. the charge to size ratio of cobalt is higher than that of calcium, the bonds formed by cobalt are therefore stronger than calcium. Thus, when cobalt content is increased, the weaker $\mathrm{Ca}-\mathrm{O}$ bonds are replaced by stronger CoO bonds which makes cleavage of the bonds difficult and therefore the glasses less soluble in aqueous media.

Since the addition of cobalt oxide reduces the rate of dissolution. It is important to take this into consideration when designing bioactive glasses. Incorporating $10 \% \mathrm{CoO}$ compared to $1 \% \mathrm{CoO}$ will not simply increase cobalt ion leaching by a factor of 10 . For the present glasses the weight loss in distilled water are 3.8 and $1.4 \mathrm{mg} \cdot \mathrm{cm}^{-2}$. day ${ }^{-1}$ for the $1 \%$ and $10 \%$ doped CoO. Therefore one would anticipate an increase in cobalt ion release by just a factor of $\sim 3.7$ given that the dissolution reduces by a factor of 2.7. This result is indeed confirmed in Figure $5 \mathrm{~d}$ where concentrations of Co of 51 and $13.5 \mathrm{ppm}$ are observed for the 10 and $1 \%$ Co glasses respectively giving a ratio of $3.8(1)$. 
The dissolution rate of bioactive glasses depends not only on their chemical stability but also on the nature of the media and its $\mathrm{pH}$. Since the ionic strength of nutrient broth is higher than that of distilled water glass dissolution is supressed in nutrient broth relatively. A higher or lower $\mathrm{pH}$ can also promote glass dissolution. Nutrient broth also tends to buffer the $\mathrm{pH}$ of the system which explains why lower dissolution rates were observed in nutrient broth.

To date the majority of hypoxia mimicking glasses have focused on silicate based glasses [23, 3037]. Relative few studies have been undertaken on cobalt doped phosphate glasses and studies that have been undertaken were co-doped with titanium dioxide $[40,41]$. The present study shows that sodium calcium phosphate is a suitable controlled release glass capable of delivering biologically relevant concentrations of cobalt ions. VEGF mRNA expression was found to increase by a factor of 5 for SAOS-2 cells exposed to $10 \% \mathrm{CoO}$ compared to the $0 \% \mathrm{CoO}$ control glass. Similarly a 4 -fold increase was observed for THP-1 cells exposed to $10 \% \mathrm{CoO}$ compared to $0 \% \mathrm{CoO}$ control glass.

The antimicrobial effect was determined using direct (ISO-22196) and indirect contact (effect of glass dissolution products) method. The results of direct contact showed a strong, time dependent, antimicrobial activity by cobalt oxide doped glasses compared to control specimens against E. coli, S. aureus and C. albicans. Whilst an antimicrobial effect was seen against the three strains studied, E. coli showed higher susceptibility compared to $S$. aureus and C. albicans. The higher susceptibility of $E$. coli is in agreement with several studies for cobalt free bioactive glasses [42, 43]. The indirect contact experiments were conducted to investigate the antimicrobial efficacy of metal ions leached from the given glasses. The results show that the number of cobalt ions required to illicit a toxic effect was not achieved in the test media, as the dissolution products failed to exhibit bacteriostatic/bactericidal effect against any of the test strains.

The variation in the results obtained with the two methods could be attributed to the varied mechanism of action involved when microorganisms are in direct or indirect contact with antimicrobial surface. Whilst a limited literature is available on the exact mechanism of action, nonetheless several factors 
are believed to play a role in contact mediated killing. When microorganisms are in direct contact with an antimicrobial surface, bioactive glasses in the present case, it damages the outer membrane by creating holes which leads to loss of membrane potential. Additionally, reactive oxygen species are produced at the interface of microbial cell wall and the bioactive glass surface causing further structural damage to the membrane. The loss of membrane integrity results in leakage of the cell contents and thus cell death occurs. This has also been shown by studies conducted on metallic copper as an antimicrobial $[44,45]$. A reduced level of ionic species was observed following a complete kill which suggested membrane leakage was observed [46].

For indirect contact assays, the efficacy of bioactive glasses depends on their solubility and release of constituent ions such as calcium, sodium, phosphorus and cobalt. These ions then enter the microbial cells via non-specific ion channels and can target various cell components directly and indirectly to bring about cell death. Metal ions produce reactive oxygen species that results in oxidative damage to DNA, mitochondria and proteins restricting cell growth and metabolism [47, 48]. The ions can also affect microorganisms indirectly by binding to enzymes and inducing conformational changes thus making them non-functional. Subsequently microorganisms fail to carry out metabolic processes and hence death occurs. Since the presence of metal ions is essential, the lack of antimicrobial activity could therefore be due to reduction in the availability of free ions in solution. Microbiological media such as nutrient broth provides a complex environment with several ionic species that may reduce the concentration of free metal ions by precipitation or by the formation of soluble complexes [49]. Silver ions have been shown to form insoluble silver salts when in contact with large amounts of ions such as chlorides and amino acids present in broth, thus causing inactivation of silver ions [50]. Similarly, a study on zinc doped bioactive glasses showed that the amount of zinc ions leached from the glass was reduced by the formation of complexes between zinc ions and components of broth [51].

The lack of activity in the suspension experiments could also be due to the buffering capacity of nutrient broth as demonstrated in the $\mathrm{pH}$ analysis. One of the most widely accepted mode of action 
of glasses in solution is via a rapid change in the $\mathrm{pH}$ of the surrounding medium. A study by Brown et al., confirmed that a rapid change in the $\mathrm{pH}$ causes reduction in bacterial viability. Similar results were also reported by Stoor et al. and Allan et al. [52-54] therefore we can argue that the lack of activity of the glasses observed in the indirect contact study could be due to the neutralization of the $\mathrm{pH}$ to near optimal range.

It is important to note that whilst $\mathrm{pH}$ may have played a role in the observed antimicrobial results observed for the direct contact studies the antimicrobial results were strongly dependant on the cobalt oxide concentration. It is difficult to compare the present results directly with existing literature given that a range of methods have been employed previously, many of the previous studies have not used the international protocols and/or previous studies have used different bacterial strains. However the direct contact antimicrobial efficacy of cobalt doped glasses appears to be highly promising. Even at low concentrations ( 1 and 3 mol \%) significant antimicrobial activity $(\mathrm{R}>2)$ was observed against all microbes. The 5 and $10 \% \mathrm{CoO}$ provided a complete kill against $E$. coli within 4 hours. At six hours all glasses provided a complete kill against $E$. coli except for the $0 \%$ control glass. All glasses except the control glass $(0 \%)$ provided a significant antimicrobial activity against $C$. albicans within 6 hours and a complete kill within 24 hours. In addition, a significant antimicrobial activity $(\mathrm{R}>2)$ was recorded against S. aureus within 6 hours and for the $10 \% \mathrm{CoO}$ the antimicrobial activity approached 4 after 24 hours. Mulligan et. al. have reported a 0.8-0.9 log reduction for bioactive glasses containing $5 \%$ copper oxide and a of 1.0-1.3 log reduction for glasses containing $10 \%$ copper oxide against $S$. sanguinis [15]. Amhed et. al. have reported a $\sim 2 \log$ reduction in 24 hours for 5\% AgO glasses against S. aureus [12]. Valapappil et. al. have reported a $1.7 \log$ reduction against $S$. aureus in biofilms for phosphate glasses containing $10 \%$ silver oxide [55]. Valapappil et. al. have reported a $0.86 \log$ reduction against $P$. aeruginosa for phosphate glasses containing $10 \%$ gallium oxide [56]. 


\section{Conclusion}

A series of cobalt doped phosphate glasses were successfully prepared with no sign of crystallisation. The concentration of cobalt ions released from the glasses within 24 hours are within therapeutic range (10-14 ppm) reported for cobalt. Cobalt doped phosphate glasses significantly upregulated VEGF mRNA expression in the SAOS-2 and THP-1 human cell lines, and conditioned medium taken from THP-1 cells exposed to this glass stimulated the formation of tubular blood vessel-like structures in a HUVEC angiogenesis assay. Therefore cobalt doped phosphate glasses may have significant potential for angiogenic applications.

The present study suggests that cobalt doped bioactive glasses can be developed with dual functionality including antimicrobial properties. The study showed a complete kill of Gram negative Escherichia coli (NCTC 10538) within 6 hours under direct contact conditions and a complete kill of Candida albicans (ATCC 76615) within 24 hours. All glasses showed an antimicrobial effect (R $>2$ ) within 6 hours for Staphylococcus aureus (ATCC 6538) whilst at 24 hours the kill was dependant on cobalt concentration.

\section{Notes}

The authors declare no competing financial interest.

\section{ACKNOWLEDGEMENTS}

The authors gratefully acknowledge Insight Health Ltd, UK and ARCHA (Aston Research Centre for Healthy Ageing) for financial support.

\section{References}

1. Yasuyuki, M., et al., Antibacterial properties of nine pure metals: a laboratory study using Staphylococcus aureus and Escherichia coli. Biofouling, 2010. 26(7): p. 851-858. DOI: 10.1080/08927014.2010.527000

2. Marchetti, F., et al., Novel Composite Plastics Containing Silver(I) Acylpyrazolonato Additives Display Potent Antimicrobial Activity by Contact. Chemistry-a European Journal, 2015. 21(2): p. 836-850. DOI: 10.1002/chem.201404812

3. Gerba, C.P., et al., Wide-spectrum activity of a silver-impregnated fabric. American journal of infection control, 2016. 44(6): p. 689-90. DOI: 10.1016/j.ajic.2015.11.033 
4. Lysenko, O., et al., The biological properties of the silver- and copper-doped ceramic biomaterial. Journal of Nanoparticle Research, 2015. 17(4): p. 15. DOI 10.1007/s11051015-2971-z

5. Storey, S., et al., A comparative evaluation of antimicrobial coated versus nonantimicrobial coated peripherally inserted central catheters on associated outcomes: A randomized controlled trial. American journal of infection control, 2016. 44(6): p. 636-41. DOI: 10.1016/j.ajic.2015.11.017

6. Lorente, L., Antimicrobial-impregnated catheters for the prevention of catheter-related bloodstream infections. World journal of critical care medicine, 2016. 5(2): p. 137-42. DOI: 10.5492/wjccm.v5.i2.137

7. Ferraris, S. and S. Spriano, Antibacterial titanium surfaces for medical implants. Materials Science \& Engineering C-Materials for Biological Applications, 2016. 61: p. 965-978. DOI: 10.1016/j.msec.2015.12.062

8. Miguez-Pacheco, V., et al., Bioactive glasses in soft tissue repair. Am. Ceram. Soc. Bull, 2015. 94: p. 27-31.

9. Hench, L.L. and J.R. Jones, Bioactive glasses: frontiers and challenges. Frontiers in bioengineering and biotechnology, 2015. 3: p. 194. DOI: 10.3389/fbioe.2015.00194

10. Lakhkar, N.J., et al., Titanium phosphate glass microspheres for bone tissue engineering. Acta Biomaterialia, 2012. 8(11): p. 4181-4190. DOI: 10.1016/j.actbio.2012.07.023

11. Ahmed, I., et al., The structure and properties of silver-doped phosphate-based glasses. Journal of Materials Science, 2007. 42(23): p. 9827-9835. DOI 10.1007/s10853-007-2008-9

12. Ahmed, I., et al., Antimicrobial effect of silver-doped phosphate-based glasses. Journal of Biomedical Materials Research Part A, 2006. 79A(3): p. 618-626. DOI: 10.1002/jbm.a.30808

13. Mulligan, A.M., M. Wilson, and J.C. Knowles, Effect of increasing silver content in phosphate-based glasses on biofilms of Streptococcus sanguis. Journal of Biomedical Materials Research Part A, 2003. 67A(2): p. 401-412. DOI: 10.1002/jbm.a.10052

14. Abou Neel, E.A., et al., Characterisation of antibacterial copper releasing degradable phosphate glass fibres. Biomaterials, 2005. 26(15): p. 2247-2254. DOI: 10.1016/j.biomaterials.2004.07.024

15. Mulligan, A.M., M. Wilson, and J.C. Knowles, The effect of increasing copper content in phosphate-based glasses on biofilms of Streptococcus sanguis. Biomaterials, 2003. 24(10): p. 1797-1807. doi:10.1016/S0142-9612(02)00577-X

16. Chopra, I., The increasing use of silver-based products as antimicrobial agents: a useful development or a cause for concern? Journal of Antimicrobial Chemotherapy, 2007. 59(4): p. 587-590. DOI: 10.1093/jac/dkm006

17. Santo, C.E., P.V. Morais, and G. Grass, Isolation and Characterization of Bacteria Resistant to Metallic Copper Surfaces. Applied and Environmental Microbiology, 2010. 76(5): p. 1341-1348. DOI: 10.1128/AEM.01952-09

18. Jain, R.K., et al., Engineering vascularized tissue. Nature biotechnology, 2005. 23(7): p. 821. DOI: $10.1038 / \mathrm{nbt0705-821}$

19. Buttyan, R., et al., Acute intravesical infusion of a cobalt solution stimulates a hypoxia response, growth and angiogenesis in the rat bladder. The Journal of urology, 2003. 169(6): p. 2402-2406. DOI: 10.1097/01.ju.0000058406.16931.93

20. Azevedo, M.M., et al., Hypoxia inducible factor-stabilizing bioactive glasses for directing mesenchymal stem cell behavior. Tissue Engineering Part A, 2014. 21(1-2): p. 382-389. DOI: $10.1089 /$ ten. TEA.2014.0083

21. Chachami, G., et al., Cobalt induces hypoxia-inducible factor-1a expression in airway smooth muscle cells by a reactive oxygen species-and PI3K-dependent mechanism. American journal of respiratory cell and molecular biology, 2004. 31(5): p. 544-551. DOI: 10.1165/rcmb.2003-04260C

22. Tanaka, T., et al., Cobalt promotes angiogenesis via hypoxia-inducible factor and protects tubulointerstitium in the remnant kidney model. Laboratory investigation, 2005. 85(10): p. 1292. DOI: $10.1038 /$ labinvest. 3700328

23. Azevedo, M.M., et al., Synthesis and characterization of hypoxia-mimicking bioactive glasses for skeletal regeneration. Journal of Materials Chemistry, 2010. 20(40): p. 88548864. DOI:10.1039/COJM01111H 
24. Hoppe, A., N.S. Güldal, and A.R. Boccaccini, A review of the biological response to ionic dissolution products from bioactive glasses and glass-ceramics. Biomaterials, 2011. 32(11): p. 2757-2774. DOI: 10.1016/j.biomaterials.2011.01.004

25. Saima, B., et al., The influence of $\mathrm{pH}$ and fluid dynamics on the antibacterial efficacy of 45S5 Bioglass. Biomedical Materials, 2016. 11(1): p. 015006. DOI: 10.1088/17486041/11/1/015006

26. Soper, A.K., GudrunN and GudrunX: programs for correcting raw neutron and X-ray diffraction data to differential scattering cross section. 2011: Science \& Technology Facilities Council.

27. Staples, K.J., et al., Monocyte-derived macrophages matured under prolonged hypoxia transcriptionally up-regulate HIF-1a mRNA. Immunobiology, 2011. 216(7): p. 832-839. DOI: 10.1016/j.imbio.2010.12.005

28. ISO, International Standard, Plastics - Measurement of Antibacterial Activity on Plastics Surfaces. International Organization for Standardization, 2007 edn.

29. Sanders, E.R., Aseptic Laboratory Techniques: Plating Methods. Journal of Visualized Experiments : JoVE, 2012(63): p. 3064. DOI: 10.3791/3064

30. Littmann, E., et al., Cobalt-containing bioactive glasses reduce human mesenchymal stem cell chondrogenic differentiation despite HIF-1 alpha stabilisation. Journal of the European Ceramic Society, 2018. 38(3): p. 877-886. DOI: 10.1016/j.jeurceramsoc.2017.08.001

31. Kargozar, S., et al., Strontium- and cobalt-substituted bioactive glasses seeded with human umbilical cord perivascular cells to promote bone regeneration via enhanced osteogenic and angiogenic activities. Acta Biomaterialia, 2017. 58: p. 502-514. DOI: 10.1016/j.actbio.2017.06.021

32. Kargozar, S., et al., Synthesis, physico-chemical and biological characterization of strontium and cobalt substituted bioactive glasses for bone tissue engineering. Journal of Non-Crystalline Solids, 2016. 449: p. 133-140. DOI: 10.1016/j.jnoncrysol.2016.07.025

33. Noor, S., et al., Hypoxia-mimicking Bioactive Glass Regenerative Effects on Dental Stem Cells, in Translational Craniofacial Conference 2016, K.T. Das, et al., Editors. 2016. DOI: $10.1063 / 1.4968864$

34. Vyas, V.K., et al., Effect of Cobalt Oxide Substitution on Mechanical Behaviour and Elastic Properties of Bioactive Glass and Glass-Ceramics. Transactions of the Indian Ceramic Society, 2016. 75(1): p. 12-19. DOI: 10.1080/0371750X.2016.1149098

35. Hoppe, A., et al., In vitro cell response to Co-containing 1393 bioactive glass. Materials Science \& Engineering C-Materials for Biological Applications, 2015. 57: p. 157-163. DOI: 10.1016/j.msec.2015.07.014

36. Hoppe, A., et al., Cobalt-Releasing 1393 Bioactive Glass-Derived Scaffolds for Bone Tissue Engineering Applications. Acs Applied Materials \& Interfaces, 2014. 6(4): p. 2865-2877. DOI: 10.1021/am405354y

37. Smith, J.M., et al., Structural characterisation of hypoxia-mimicking bioactive glasses. Journal of Materials Chemistry B, 2013. 1(9): p. 1296-1303. DOI:10.1039/C3TB00408B

38. Valappil, S.P., et al., Antimicrobial gallium-doped phosphate-based glasses. Advanced functional materials, 2008. 18(5): p. 732-741. DOI: 10.1002/adfm.200700931

39. Uo, M., et al., Properties and cytotoxicity of water soluble Na 2 O-CaO-P 2 O 5 glasses. Biomaterials, 1998. 19(24): p. 2277-2284. DOI: 10.1016/S0142-9612(98)00136-7

40. Peticone, C., et al., Towards modular bone tissue engineering using Ti-Co-doped phosphate glass microspheres: cytocompatibility and dynamic culture studies. Journal of Biomaterials Applications, 2017. 32(3): p. 295-310. DOI: $10.1177 / 0885328217720812$

41. Lee, I.H., et al., Development, characterisation and biocompatibility testing of a cobaltcontaining titanium phosphate-based glass for engineering of vascularized hard tissues. Materials Science \& Engineering C-Materials for Biological Applications, 2013. 33(4): p. 2104-2112. DOI: 10.1016/j.msec.2013.01.024

42. Hu, S., et al., Study on antibacterial effect of $45 S 5$ Bioglass $(A(R))$. Journal of Materials Science-Materials in Medicine, 2009. 20(1): p. 281-286. DOI: 10.1007/s10856-008-3564-5

43. Begum, S., et al., The influence of $\mathrm{pH}$ and fluid dynamics on the antibacterial efficacy of 45S5 Bioglass. Biomedical Materials, 2016. 11(1). DOI: 10.1088/1748-6041/11/1/015006

44. Grass, G., C. Rensing, and M. Solioz, Metallic copper as an antimicrobial surface. Applied and environmental microbiology, 2011. 77(5): p. 1541-1547. DOI: 10.1128/AEM.02766-10 
45. Santo, C.E., et al., Bacterial killing by dry metallic copper surfaces. Applied and environmental microbiology, 2011. 77(3): p. 794-802. DOI: 10.1128/AEM.01599-10

46. Santo, C.E., D. Quaranta, and G. Grass, Antimicrobial metallic copper surfaces kill Staphylococcus haemolyticus via membrane damage. Microbiologyopen, 2012. 1(1): p. 4652. DOI: $10.1002 / \mathrm{mbo} .2$

47. Fang, F.C., Antimicrobial actions of reactive oxygen species. MBio, 2011. 2(5): p. e0014111. DOI: $10.1128 / \mathrm{mBio} .00141-11$

48. Vatansever, F., et al., Antimicrobial strategies centered around reactive oxygen speciesbactericidal antibiotics, photodynamic therapy, and beyond. FEMS microbiology reviews, 2013. 37(6): p. 955-989. DOI: 10.1111/1574-6976.12026

49. Avent, A.G., et al., The dissolution of silver-sodium-calcium-phosphate glasses for the control of urinary tract infections. Journal of Non-Crystalline Solids, 2003. 328(1-3): p. 3139. DOI: 10.1016/S0022-3093(03)00476-9

50. Schierholz, J.M., et al., Silver-containing polymers. Antimicrobial agents and chemotherapy, 1999. 43(11): p. 2819-2821.

51. Li, M., L. Zhu, and D. Lin, Toxicity of ZnO nanoparticles to Escherichia coli: mechanism and the influence of medium components. Environmental science \& technology, 2011. 45(5): $p$. 1977-1983. DOI: $10.1021 / \mathrm{es} 102624 \mathrm{t}$

52. Stoor, P., E. Soderling, and J.I. Salonen, Antibacterial effects of a bioactive glass paste on oral microorganisms. Acta Odontologica Scandinavica, 1998. 56(3): p. 161-165.

53. Allan, I., H. Newman, and M. Wilson, Antibacterial activity of particulate Bioglass (R) against supra- and subgingival bacteria. Biomaterials, 2001. 22(12): p. 1683-1687. DOI: 10.1016/S0142-9612(00)00330-6

54. Brown, L., M. Darmoc, and M. Havener. Antibacterial Effects of 4555 Bioactive Glass against Four Clinically Relevant Bacterial Species. in 55 th annual meeting of the Orthopedic Research Society. 2009.

55. Valappil, S.P., et al., Effect of silver content on the structure and antibacterial activity of silver-doped phosphate-based glasses. Antimicrobial Agents and Chemotherapy, 2007. 51(12): p. 4453-4461. DOI: 10.1128/AAC.00605-07

56. Valappil, S.P., et al., Controlled delivery of antimicrobial gallium ions from phosphate-based glasses. Acta Biomaterialia, 2009. 5(4): p. 1198-1210. DOI: 10.1016/j.actbio.2008.09.019 
For Table of Contents Use Only

The antimicrobial efficacy of hypoxia mimicking cobalt oxide doped phosphate-based glasses against clinically relevant Gram positive, Gram negative bacteria and a fungal strain.

Farah N. S. Raja, T. Worthington, Mark A. Isaacs, Louis Forto Chungong, Bernard Burke, Owen Addison and Richard A. Martin.

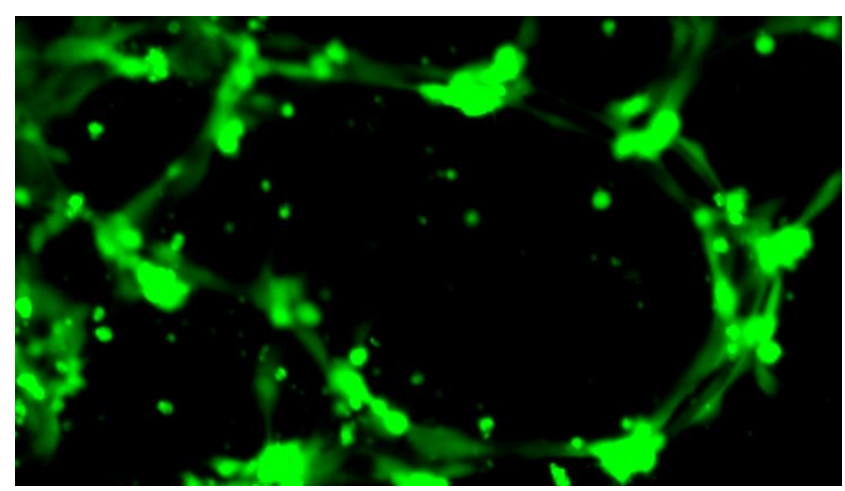




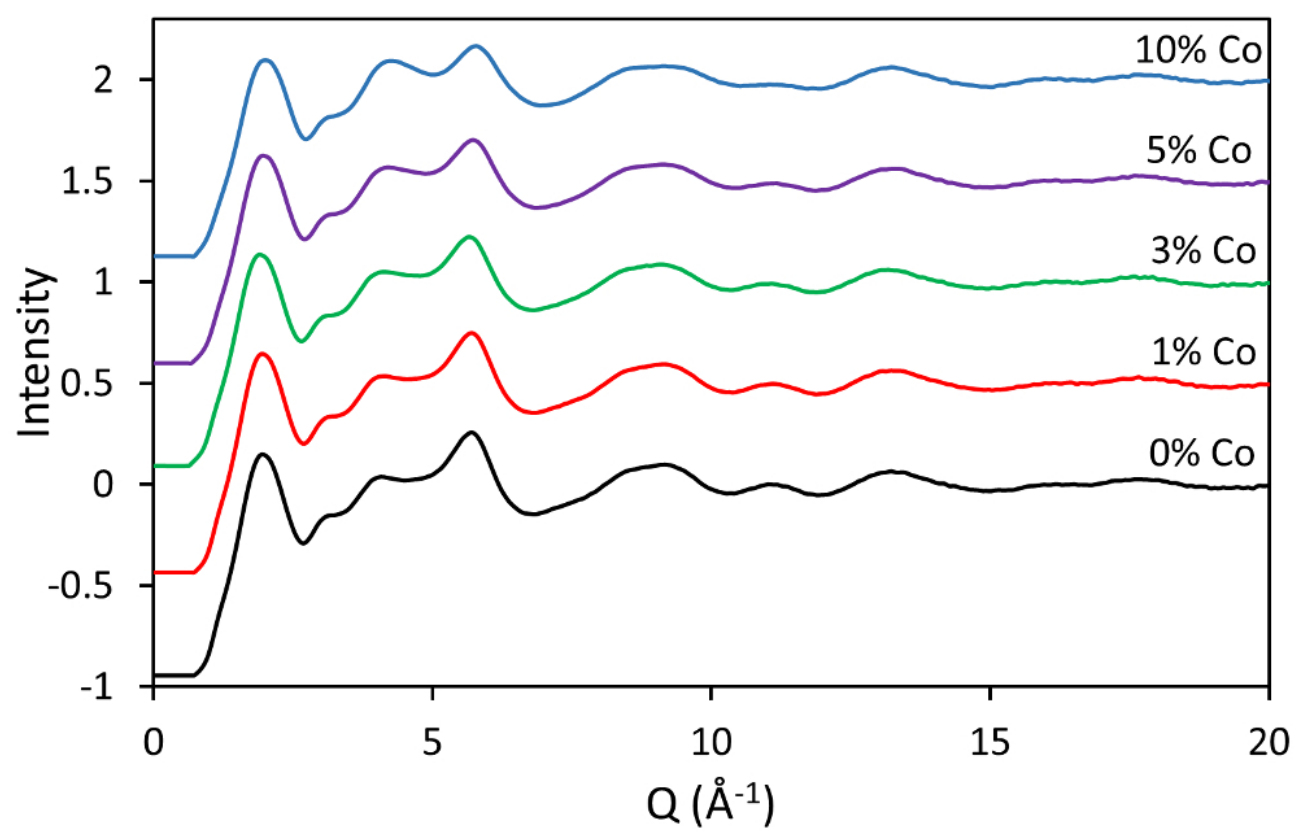

Figure 1. X-ray diffraction spectra, illustrating the absence of Bragg peaks.

$85 \times 55 \mathrm{~mm}(300 \times 300$ DPI $)$ 
Figure 2: The degradation profiles obtained for $0,13,5$ and $10 \mathrm{~mol} \% \mathrm{CoO}$ compositions, investigated in distilled water and nutrient broth. Error bars $= \pm S D$ for triplicate samples.

$169 \times 59 \mathrm{~mm}(300 \times 300$ DPI $)$ 

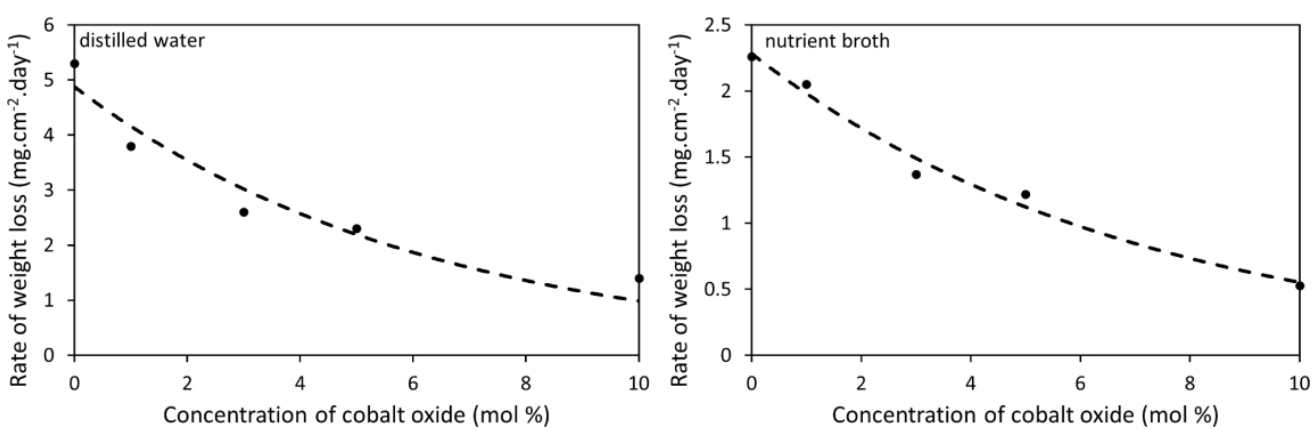

Figure 3. The rate of weight loss of the phosphate glasses as a function of cobalt oxide concentration, when placed in distilled water and nutrient broth.

$167 \times 52 \mathrm{~mm}(300 \times 300$ DPI $)$ 

phosphate glasses. $170 \times 59 \mathrm{~mm}(300 \times 300 \mathrm{DPI})$
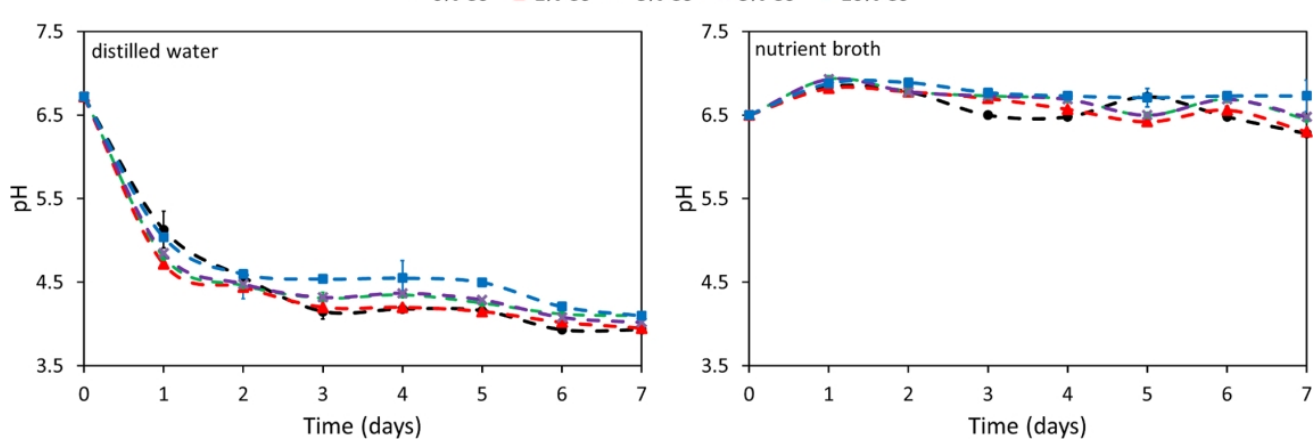

\section{Figure 4. Resultant $\mathrm{pH}$ as a function of time for distilled water and nutrient broth containing cobalt doped}


- $0 \%$ Co $\Delta 1 \%$ Co $-3 \%$ Co $\times 5 \%$ Co $=10 \%$ Co
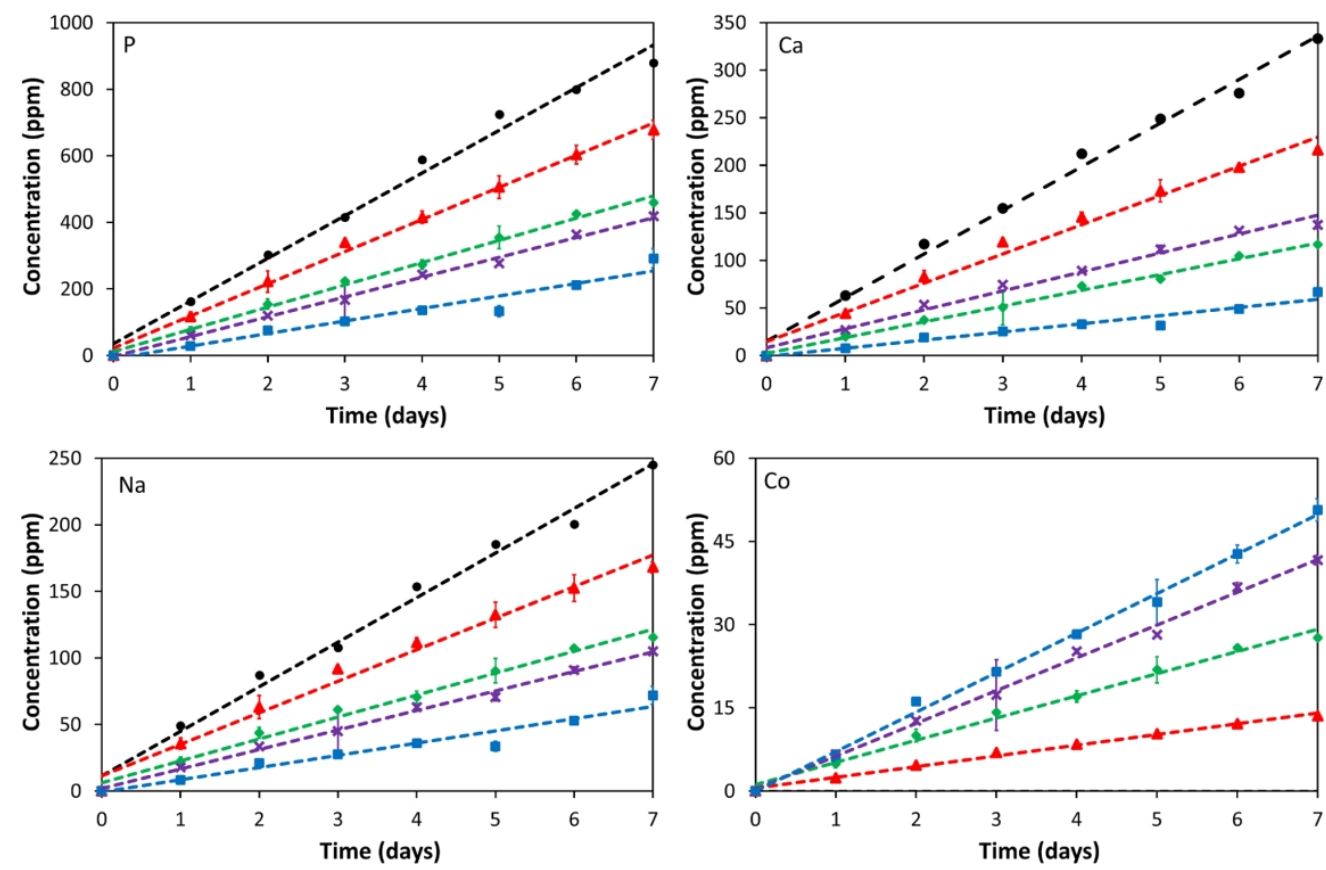

Figure 5: Accumulative ion release phosphorous, calcium, sodium and cobalt as a function of time for 0,1 , 3,5 and $10 \mathrm{~mol} \%$ cobalt doped glasses. (Error bars $= \pm S D$ for triplicate samples).

$170 \times 116 \mathrm{~mm}(300 \times 300 \mathrm{DPI})$ 

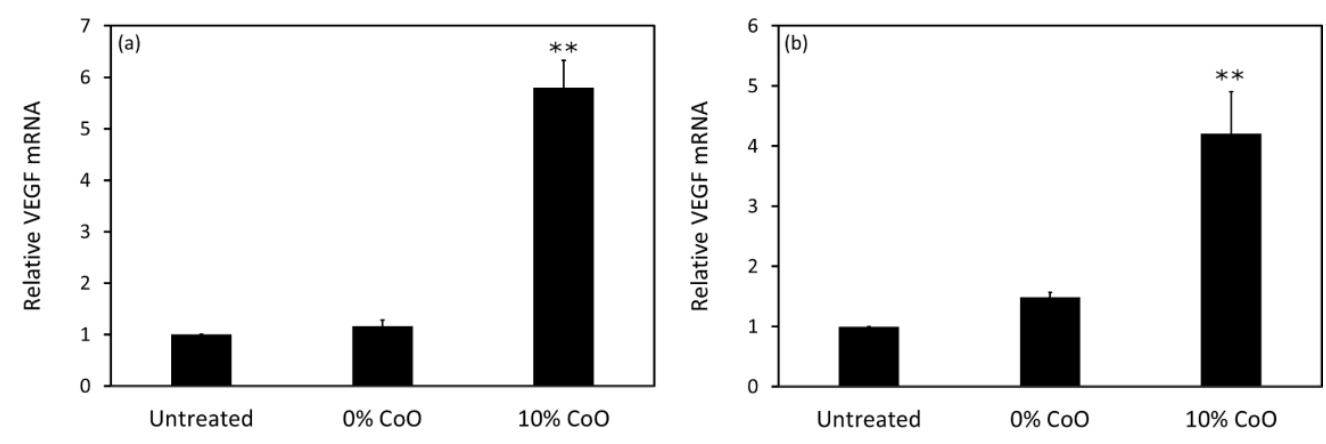

Figure 6. Relative VEGF mRNA expression for (a) SAOS-2 cells and (b) THP-1 cells. $167 \times 52 \mathrm{~mm}(300 \times 300 \mathrm{DPI})$ 

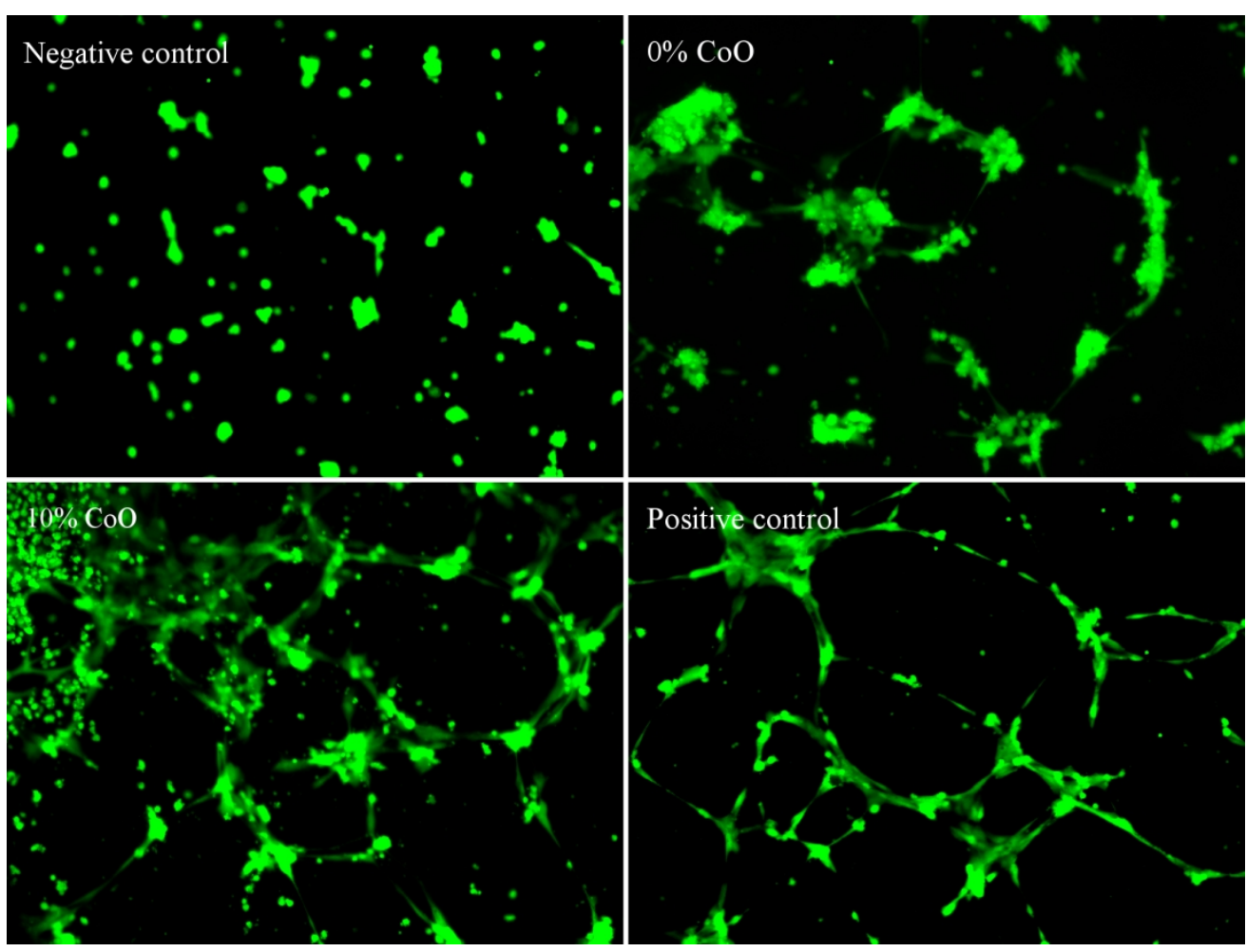

Figure 7. Overlaid fluorescent and brightfield images of endothelial cells stimulated for 4 hours with medium extracted from cell cultures of untreated THP-1 monocytes (negative control), or with medium from THP-1 cells treated with $0 \%$ or $10 \% \mathrm{CoO}$ doped phosphate glasses for 24 hours. The positive control was treated with known pro-angiogenic factors.

$170 \times 127 \mathrm{~mm}(300 \times 300 \mathrm{DPI})$ 
E. coli

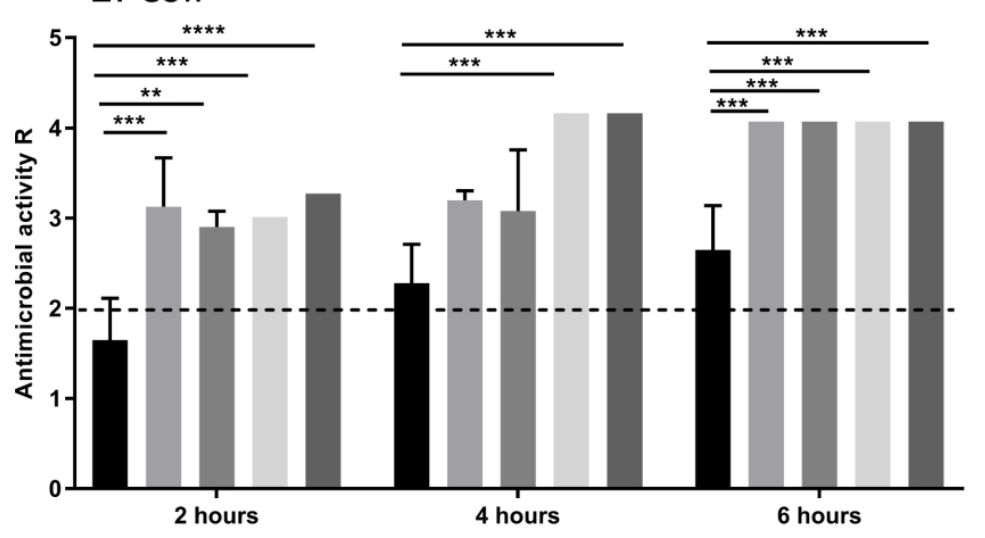

- $0 \mathrm{~mol} \%$

$1 \mathrm{~mol} \%$

$3 \mathrm{~mol} \%$

$5 \mathrm{~mol} \%$

- $10 \mathrm{~mol} \%$

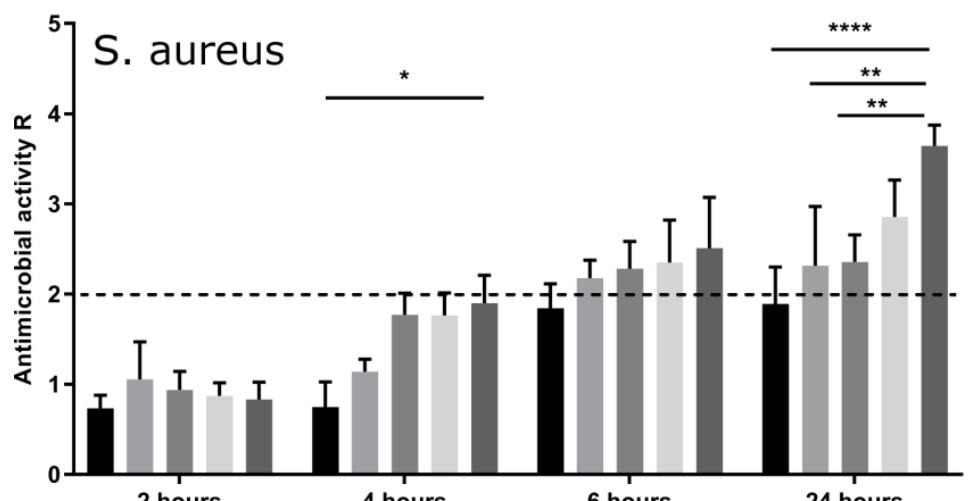

- $0 \mathrm{~mol} \%$

- $1 \mathrm{~mol} \%$

- $3 \mathrm{~mol} \%$

$5 \mathrm{~mol} \%$

- $10 \mathrm{~mol} \%$

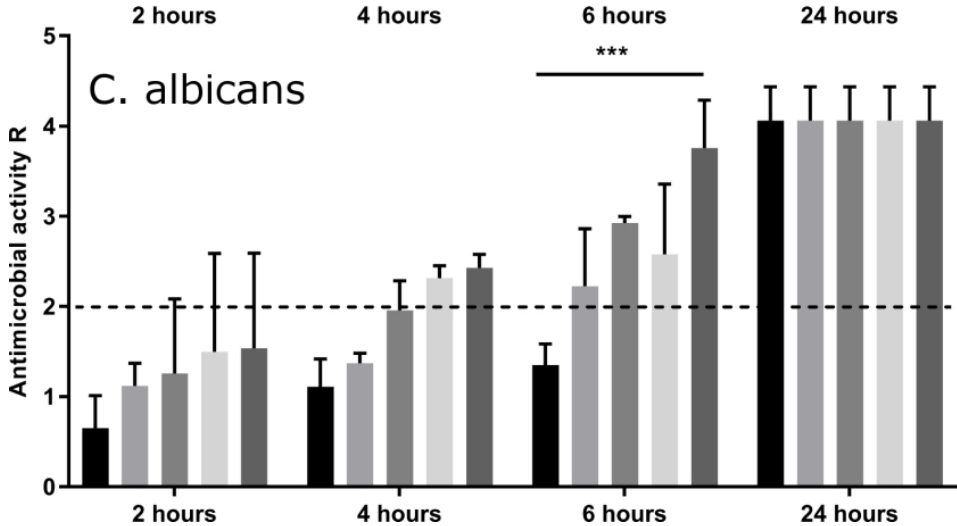

$0 \mathrm{~mol} \%$

$1 \mathrm{~mol} \%$

$3 \mathrm{~mol} \%$

$5 \mathrm{~mol} \%$

$10 \mathrm{~mol} \%$

Figure 8: The antimicrobial efficacy of un-doped phosphate glass and 1, 3, 5 and $10 \mathrm{~mol} \%$ cobalt doped phosphate glass against E. coli, S. aureus, C. albicans over a 24 hours period. Data shown are expressed as mean \pm SD $(\mathrm{N}=3)$ antibacterial activity as determined by ISO-22196.

$170 \times 221 \mathrm{~mm}(300 \times 300 \mathrm{DPI})$ 

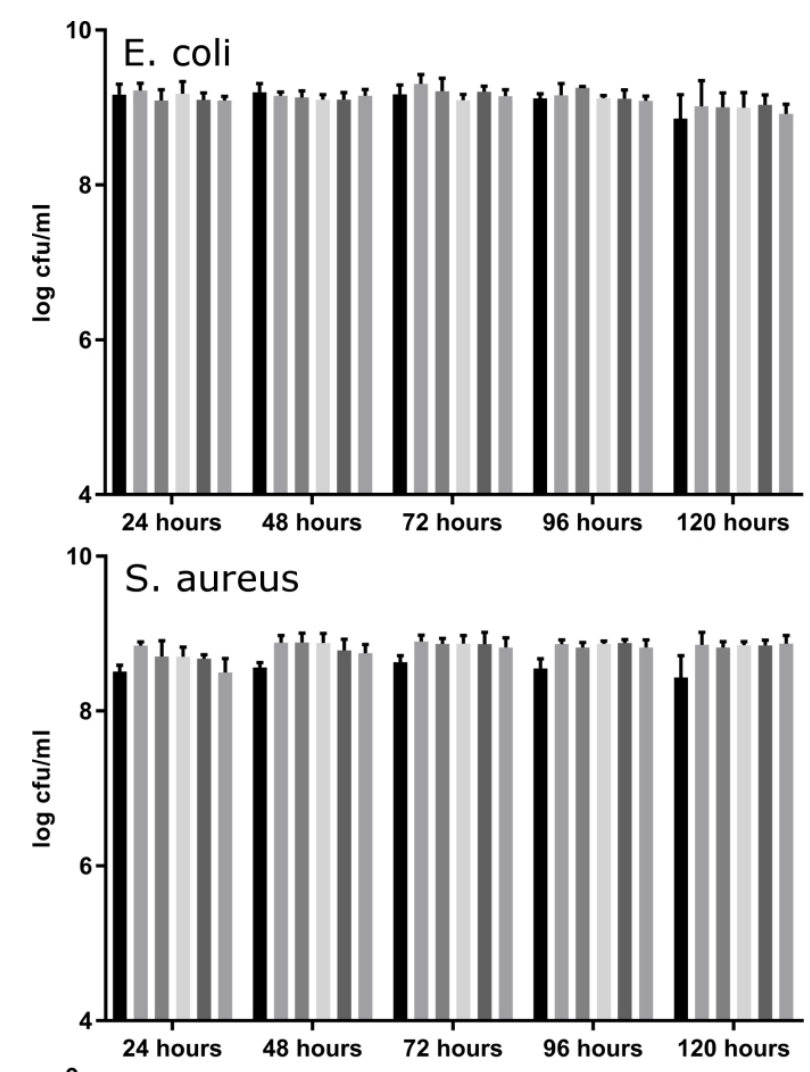

- Control

- $0 \mathrm{~mol} \%$

$1 \mathrm{~mol} \%$

$3 \mathrm{~mol} \%$

- $5 \mathrm{~mol} \%$

- $10 \mathrm{~mol} \%$

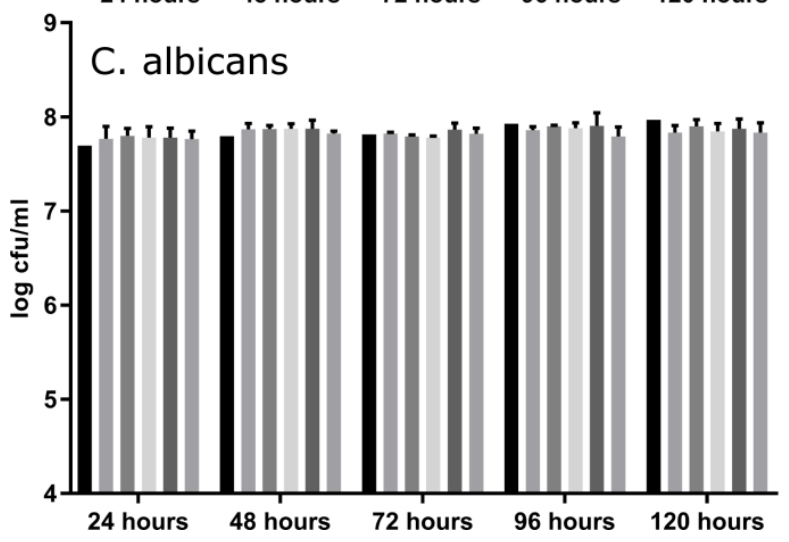

- Control

$0 \mathrm{~mol} \%$

$1 \mathrm{~mol} \%$

$3 \mathrm{~mol} \%$

$5 \mathrm{~mol} \%$

- $10 \mathrm{~mol} \%$

Figure 9: The effect of dissolution products of un-doped phosphate glass and 1, 3, 5 and 10 mol \% cobalt doped phosphate glass against E. coli, S. aureus and C. albicans over a 5 days period. Data shown are expressed as mean $\pm \mathrm{SD}(\mathrm{N}=3)$.

$170 \times 258 \mathrm{~mm}(300 \times 300 \mathrm{DPI})$ 